\title{
LINKING MARKEMES IN RUSSIAN AND BRITISH LITERARY TEXTS OF THE FIRST HALF OF THE NINETEENTH CENTURY
}

\author{
O.G. Artemova, A.A. Verbitskiy, E.P. Komarova, A.A. Kretov
}

\begin{abstract}
The paper aims at visualizing and analyzing the markeme links in literary texts of Russian and British writers of the first half of nineteenth century. According to the target goal, the tasks of determining the preferred markeme links between the authors, substantial study of maximum force markeme links and comparing the linking markeme vocabulary in Russian and English literary texts have been solved. The topicality of this study is conditioned by the need to devise the ways of cognitive-graphical representations of analytic data and their semantic interpretation and by the scarcity of comparative quantitative studies of the language of Russian and English literary texts, which could present information for comparative and typological analysis of language and literary processes. The study of markeme links is one of the ways of formalized content analysis of the text. The scientists identified regularities to which the texts in natural languages are subject. This enables the use of the mathematical apparatus in linguistic studies. The use of both digital and traditional linguistic studies methods allows analyzing text corpora with mathematical and statistical methods and composing national text corpora, corpora of translations, interactive maps, creating social networks of writers, poets, philosophers, modeling script texts into picture line, analyzing text sentiment, running network analysis and so on. This article suggests analyzing markeme links of maximum force in pairs of authors when comparing "with each other". The method of markeme analysis proposed by A.A. Kretov as one of the means to formalize the semantical analysis of the text is used to solve the set tasks. It provides a means of presenting a complete picture of literary works language markeme composition of any chronological interval or historical period. It also gives the possibility to analyze texts practically of any wordage. Besides the method of markeme analysis allows analyzing markeme composition of literary (especially - fiction) works of individual authors or groups of authors, markeme specifications and the influence of social and cultural processes on markeme dynamics, studying the evolution of markeme vocabulary through several chronological intervals and establishing literary and genetic links between authors who belong to the same or different chronological intervals an individual DH prospect developed by A.A. Kretov, his colleagues and scholars. Its potential is not limited with solving the given problems. As a qualitative and quantitative analysis, markemological studies employ markeme analysis as a method. This method allows formalizing semantic analysis of texts. Markeme analysis is a method of computer-based identification of keywords, or markemes, followed by visualization of obtained data in the form of bar graphs, charts, graphs, clusters that undergo semantic interpretation. A.A. Kretov developed sharply defined notions on how to identify markemes using a special formula to calculate author's weight or Index of Textual Markedness. The computational formula expresses functionality between a frequency weight and a length weight of a word. As the length weight of a word is constant because it depends on the length of the word in letters or
\end{abstract}


sounds, it is the value of frequency weight that determines the value of InTeM. When a word distribution in the text exceeds a standard frequency distribution threshold for this word, the value of its InTeM becomes positive thereby expressing the level of significance for the word in the particular text. The texts are processed with word thematic analysis manipulation programs "TemAl" and "ProTemAl-Engl" developed in Voronezh State University. "TemAl" processes Russian texts and "ProTemAl-Engl" does the same with English texts. These programs calculate the value of InTeM for each word as well. To guarantee comparability of markeme weights of different authors the procedure of normalizing InTeM values is carried out. This is due to the fact that too often there is great difference both in number of works and their length in words written by different authors and their availability in digital form. InTeM normalizing eliminates their incorrect correlation. The analysis of linking markemes that establish markeme links between two or more authors allows determining the degree of markeme similarity between the authors of chronological interval. Mutual markemes are selected from each author markeme list. Index of Markeme Similarity (IMaS) is the measurable parameter that gives possibility to determine the degree of generality of markeme lexicon of two authors. The computation of IMaS in each pair of authors belonging to the chronological interval is based on the value of total normalized indices of textual markedness of their mutual markemes. The mutual markemes of those two writers that have the largest value of IMaS are their linking markemes. The value of IMaS determines the power of markeme link. When the value of IMaS is the largest for only one writer in the pair, a directional or oriented link of maximum power is formed. In case the value of IMaS is the largest for both writers in the pair, mutually oriented link is formed between them. The present study results in the analysis of linking markemes in the texts of Russian and British writers of the first half of the nineteenth century in reference to the distinguished centre of attraction. The method of visualizing the links between the authors who belong to the same chronological interval allows to distinguish the centre of attraction and intermediate centres of zero, first and second degree, to compute the power of centripetal links, to stratify and analyze linking markemes, to study markeme specificity of the centre of attraction and to distinguish markemes that provide an indirect link between the centre of attraction and intermediate centres. The use of the algorithm of visualizing markeme relations between the authors provides a means of revealing existing centrifugal and centripetal markeme links between the writers, distinguishing the centre of attraction, identifying its major figures and the authors who have direct or indirect markeme links of maximum force with each of them. Obtained data make it possible to compute the power of the center of attraction and the semantic study of maximum force markeme links leads to the specification of both the intermediate centres that are represented by key figures of the centre of attraction and the centre of attraction itself.

Keywords: markeme, Index of Textual Markedness, Index of Markeme Similarity, centre of attraction, linking force, visualization of authors markeme similarity, British literature, Russian literature.

\section{Introduction}

System nature of the language allows applying quantitative methods for its investigation. The need to use such methods is necessitated by the im- 
possibility to solve many research problems by using qualitative methods alone. Quantitative linguistics methods are widely used for generating automated lexicographical systems, concordances, contextual dictionaries, multilingual corpus. Moreover, in addition to propelling to the next level the scientific image of language system the use of quantitative methods in linguistic researches modifies the concept of its functioning and "allows adding the structural model of language with a probabilistic component, i.e. generating structural-probabilistic model of language that has significant explanatory potential" [1: 548]. Nevertheless, in A.D. Verkhoturov's opinion, the use of mathematical apparatus does not ensure obtaining accurate and objective data, it only gives the possibility to generalize the obtained data, to present them in more organized form and to model a phenomenon [2].

\section{Earlier research studies review}

J. Miles's works kick start to the quantitative linguistics development. Quantitative methods that she used to analyze the poetic texts and the methods of presenting the results of research provided a basis for conducting similar researches in the future. The study of word-frequency when analyzing the vocabulary of English poetry of XVI-XX centuries made possible to ascertain the predominance of one-syllable words in the primary vocabulary of all English poetry and determine natural transition of the words from minority usage of preceding century to primary vocabulary. She also discovered that the continuity of poetic language is formed by the words from majority usage because they reveal greater stability in time over the words from minority usage [3]. Both foreign and Russian scientists are interested in quantitative analysis of prosaic, poetic, socio-journalistic and political texts. The study of political discourse by Harold D. Lasswell and his colleagues [4], the comparative study of the changes in the language of the $19^{\text {th }}$ century British novels by R. Heuser and Long Le-Khac [5] should be specially noted. R. Heuser, his colleagues M. Algee-Hewitt, F. Moretti, M. Gemma, E. Steiner, and other scientists accumulated great experience in quantitative analysis of different linguistic study aspects of English texts [6-9]. Japanese researcher Yasuo Urayi contributed greatly to the quantitative analysis of the language of Russian Attic prose. He developed concordances of "Russian Traveller's Letters" by N.N. Karamzin, "Captain's Daughter" by A.S. Pushkin, "A Journey from St. Petersburg to Moscow" by A.I. Radishchev. This work was a part of the project "Comparative study of $18^{\text {th }}-20^{\text {th }}$-century Russian novels through database" (project manager - professor Keizo Haiya, Hokkaido University (see [10]).

Such Russian linguists as O.V. Slugina [11], A.B. Borunov [12, 13], L.G. Kishinskaya and S.V. Kishinskiy [14], S.A. Krylov [15], B.V. Orekhov [16], Yu.I. Levin [17], A.Ya. Shaikevich, V.M. Andryushchenko, 
N.A. Rebetskaya [18] are interested in the quantitative study of the literary works' language as well.

A.A. Faustov and his colleagues put the task to find linguistic universals in literature. They proposed several approaches to finding out universals in literature such as composing the vocabulary of plots and motives in Russian literature, the study of Russian culture "constants" [19-21].

Alongside with the influence on the research activity organization the introduction of digital technologies in linguistic studies stipulated for including linguistics into developing multidisciplinary endeavor Digital Humanities (DH). Due to their interdisciplinary origin DH "possess all the methods, techniques and perspectives of knowledge connected with digital technologies in the Arts" [22]. As a new prospect in humanities research, DH first appeared in the USA and Great Britain in the mid of the $20^{\text {th }}$ century. G.V. Mozhayeva considers the processing of large data arrays from ancient manuscripts analysis to the analysis of literary works and historical documents that belong to different epochs as one of the tasks for digital technologies in humanities studies [23]. The use of both digital and traditional linguistic studies methods allows analyzing text corpora with mathematical and statistical methods and composing national text corpora, corpora of translations, interactive maps, creating social networks of writers, poets, philosophers, modeling script texts into picture line, analyzing text sentiment, running network analysis and so on [24, 25].

Markemology is an individual $\mathrm{DH}$ prospect developed by A.A. Kretov, his colleagues and scholars. As a qualitative and quantitative analysis, markemological studies employ markeme analysis as a method. This method allows formalizing semantic analysis of texts [26]. Markeme analysis is a method of computer-based identification of keywords, or markemes, followed by visualization of obtained data in the form of bar graphs, charts, graphs, clusters that undergo semantic interpretation.

A.A. Kretov developed sharply defined notions on how to identify markemes using a special formula to calculate author's weight or Index of Textual Markedness (InTeM). Besides, he set grammar and statistic specifications which a markeme should meet [27]. Markemology enables solving a large number of research problems such as the study of individual authors' literary works [28-31]; the compilation of markeme lists for one chronological interval or several chronological intervals to characterize a separate chronological interval or a historical interval, or a period, that includes several chronological intervals $[32,33]$; the description of markemes specificity for individual authors or groups of authors [34-37]; the study of markeme lexis evolution through several chronological intervals $[38,39]$; the influence of social and cultural processes on markemes dynamics [40]. What is more, markemological studies make it possible to establish literary and genetic links between authors who belong to the same or different chronologi- 
cal intervals and as a result to ascertain continuity in literature. To solve this problem, it is necessary to select mutual markemes from each author's markeme list and calculate Index of Markeme Similarity (IMaS) [41-44].

The topicality of this study is conditioned by the need to devise the ways of cognitive-graphical representations of analytic data and their semantic interpretation and by the scarcity of comparative quantitative studies of the language of Russian and English literary texts, which could present information for comparative and typological analysis of language and literary processes.

\section{Analysis Methodology}

To study linking markemes there used the method of markeme analysis. The markeme analysis problem is to determine which words markemes - express the author's system of values and in such a way to come to a non-textual level. The method involves the quantitative representation of the textual information and its statistical processing and semantic interpretation. For that purpose, it is necessary to compute the InTeM for each word in the text (for a computing formula for frequency-weight (Ч-вес) and lengthweight (Д-вес) see [45]). The value of InTeM can be either positive or negative. It is the word-frequency that determines the value of InTeM. The reason is that the value of length-weight is invariable for each word of the same length. Positive InTeM value means the exceedance of relative frequency statutory limits for the word of such length that determines its priority rating in the particular text.

To compute InTeM the texts of each author were collected into integrated text file and processed with Russian lexis thematic analysis manipulation program "TemAL" (producer - Irene Popova, project manager - I.E. Voronina, D.Sc. (Engineering), research advisor - D.Sc. (Philology)) and English lexis analysis manipulation program "ProTemAL-Engl" (producer A.S. Guselnikova, project manager - I.E. Voronina, D.Sc. (Engineering), research advisor - D.Sc. (Philology)). These programs enable both computing InTeM and ranking words in descending order of their InTeM values. All available in digital form texts of each author were processed to compute the InTeM.

When identifying markemes the attention is paid to the words, which one could consider the most significant for the author. They are abstract (without a denotation) lexis, which denotes the most important categories of culture, describe inward world and relations between individuals and society, fundamental notions that correspond to the universal philosophical concepts; words that denote natural objects and so on. As to artifacts they could be considered markemes if they matter symbolically. Thus, it is semantics that determines the word as a markeme. In case of a dispute, one should consult the context. 
Besides, a potential markeme has to pass through the system of special filters - grammatical, grammar and semantic, thematic and semantic, stylistic, dialogue, classifying. Those Russian words which are nominative singular nouns and English words in the common case that are not onyms or animate nouns, except человек, таn, creature, fellow-creature have no stylistic color, are not vocatives or classifying words are available for further analysis. They should not be a part of a construction "Noun in Nominative case + Noun in the genitive". The names of months, days of the week, literary genres, artifacts which are not symbols, words specific for a certain author / genre / art movement and the words used adverbially should also be excluded from further analysis [46].

50 markemes are considered enough for one author. Therefore, a markeme is one of 50 words that passed through all the filters and are ranked in descending order of maximum InTeM value.

As far as markeme Ч-вес (F-weight) depends particularly on the total number of words in the texts of each author and this, in its turn, depends both on the number of written works and their availability in digital form, it is necessary to balance InTeM values for each author. The following procedure allows weights comparability. We propose normalizing of InTeMs in each author's markeme list according to the formula:

$$
\text { NormInTeM }_{i}=\frac{\operatorname{InTeM}_{i}}{\sum_{i=1}^{50} \text { InTeM }_{i}},
$$

where NormInTeM - normalized InTeM, $i$ - the number of a markeme in the author's markeme list.

When InTeM of the 50th markeme coincides with InTeM of one or several following markemes the last value of $i$ is the number of the last one. Values of markemes NormInTeMs lie in the range 0-1.

Substantial analysis of maximum force markeme links between the authors of the 19-1 interval needs comparing them with each other and studying linking markemes, which provide markeme links of two or more authors and characterize the level of markeme similarity of all the authors of the interval. When identifying linking markemes only mutual markemes for each pair of authors are considered. The source of mutual markemes is each author markeme list.

IMaS is a quantitative parameter that makes possible determining the level of two authors' markeme vocabulary similarity. The formula for computing IMaS is as follows:

$$
\text { IMaS = TotNormInTe } M_{\mathrm{MM}} 1 \times \text { TotNormInTeM }_{\mathrm{MM}} 2 \text {, }
$$

where IMaS - Index of Markeme Similarity, TotNormInTeM $\mathrm{MM}_{\mathrm{M}} 1$ and TotNormInTeM $\mathrm{MM}_{\mathrm{MM}} 2$ - total normalized InTeM of mutual markemes in the pair. The values of IMaS lie in the range $0-1$.

Let us consider the pair Scott - Marryat. TotNormInTeM of Scott's mutual markemes (MM) is 0.6993 and TotNormInTeM of Marryat's MM is 
0.6622 . So, $\mathrm{IMaS}=0.6993 \times 0.6622=0.4631$. IMaS value of 0.463 rounded to three decimal places is at the intersection of the line "Sct" (Scott) and column 1 "Mrt" (Marryat).

The linking markemes are the markemes of that pair of authors in which IMaS is the largest for one or both authors. The value of IMaS characterizes the force of markeme link between two authors. If IMaS is the largest for one author, we get oriented link of maximum force.

In our example, the largest value of IMaS for Author 1 (Scott) is at the intersection with Author 2 (Marryat) and the largest value of IMaS for Author 2 (Marryat) is at the intersection with Author 1 (Scott). We call such a link between Author 1 and Author 2 a mutually oriented link.

Table 1

Indices of Markeme Similarity for the authors of 19-1 interval

\begin{tabular}{|c|c|c|c|c|c|c|c|c|c|c|c|c|c|c|c|c|}
\hline \multirow[t]{2}{*}{ Автор } & BrCh & BrA & $\begin{array}{l}\text { Bul- } \\
\text { Lyt }\end{array}$ & Gkl & DisB & DisI & Crl & Qcy & Cdge & Lmb & Mrt & Mtn & Set & Thek & Hzl & ShelM \\
\hline & 1 & 2 & 3 & 4 & 5 & 6 & 7 & 8 & 9 & 10 & 11 & 12 & 13 & 14 & 15 & 16 \\
\hline BrCh & & \begin{tabular}{|l|}
0,321 \\
\end{tabular} & 0,265 & 0,288 & 0,350 & 0,193 & 0,147 & 0,180 & 0,121 & 0,256 & 0,282 & \begin{tabular}{|l|}
0,175 \\
\end{tabular} & 0,248 & 0,237 & 0,202 & 0,163 \\
\hline BrA & 0,321 & & 0,226 & 0,266 & 0,281 & 0,179 & 0,145 & 0,174 & 0,092 & 0,376 & 0,346 & $\begin{array}{l}0,136 \\
\end{array}$ & 0,287 & 0,339 & 0,186 & 0,247 \\
\hline Bul-Lyt & 0,265 & 226 & & 0,331 & 0,354 & 0,292 & 0,131 & 0,312 & 0,220 & 0,239 & 0,364 & \begin{tabular}{|l|}
0,127 \\
\end{tabular} & 0,411 & 0,229 & 0,315 & 0,199 \\
\hline Gkl & 0,288 & 0,266 & 331 & & 0,372 & 0,204 & 0,131 & 0,204 & 0,165 & 0,195 & 0,364 & 0,089 & 0,373 & 0,255 & 0,233 & 0,177 \\
\hline DisB & \begin{tabular}{|l|}
0,350 \\
\end{tabular} & 0,281 & 0,354 & 0,372 & & 0,317 & 0,209 & 0,195 & 0,175 & 0,241 & 0,355 & 0,122 & 0,430 & 0,340 & 0,318 & 0,211 \\
\hline DisI & \begin{tabular}{|l|}
0,193 \\
\end{tabular} & \begin{tabular}{|l|}
0,179 \\
\end{tabular} & 0,292 & 0,204 & 0,317 & & 0,185 & 0,216 & 0,194 & 0,296 & 0,240 & \begin{tabular}{|l|}
0,126 \\
\end{tabular} & 0,354 & 0,323 & 0,340 & 0,202 \\
\hline Crl & \begin{tabular}{|l|}
0,147 \\
\end{tabular} & \begin{tabular}{|l|l|}
0,145 \\
\end{tabular} & 0,131 & 0,131 & 0,209 & 0,185 & & 0,165 & 0,068 & 0,183 & 0,204 & \begin{tabular}{|l|}
0,098 \\
\end{tabular} & 0,203 & 0,188 & 0,137 & 0,241 \\
\hline Qcy & \begin{tabular}{|l|}
0,180 \\
\end{tabular} & \begin{tabular}{|l|}
0,174 \\
\end{tabular} & 0,312 & 0,204 & 0,195 & 0,216 & 0,165 & & 0,203 & 0,228 & 0,348 & \begin{tabular}{|l|}
0,129 \\
\end{tabular} & 0,265 & 0,221 & 0,312 & \begin{tabular}{|l|l|}
0,173 \\
\end{tabular} \\
\hline Cdge & \begin{tabular}{|l|l|}
0,121 \\
\end{tabular} & \begin{tabular}{|l|}
0,092 \\
\end{tabular} & 0,220 & 0,165 & 0,175 & 0,194 & 0,068 & 0,203 & & 0,114 & 0,162 & \begin{tabular}{|l|}
0,057 \\
\end{tabular} & 0,188 & 089 & 0,199 & 0,072 \\
\hline Lmb & \begin{tabular}{|l|}
0,256 \\
\end{tabular} & \begin{tabular}{|l|}
0,376 \\
\end{tabular} & 0,239 & 0,195 & 0,241 & 0,296 & 0,183 & 0,228 & 0,114 & & 0,378 & \begin{tabular}{|l|}
0,200 \\
\end{tabular} & 0,306 & 0,254 & 0,198 & 0,271 \\
\hline Mrt & \begin{tabular}{|l|}
0,282 \\
\end{tabular} & 0,346 & 0,364 & 0,364 & 0,355 & 0,240 & 0,204 & 0,348 & 0,162 & 0,378 & & \begin{tabular}{|l|}
0,163 \\
\end{tabular} & 0,463 & 0,293 & 0,338 & 0,186 \\
\hline Mtn & 0,175 & 0,136 & 0,127 & 0,089 & 0,122 & 0,126 & 0,098 & 0,129 & 0,057 & 0,200 & 0,163 & & 0,149 & 0,167 & 0,071 & 0,165 \\
\hline Set & \begin{tabular}{|l|}
0,248 \\
\end{tabular} & 0,287 & 0,411 & 0,373 & 0,430 & 0,354 & 0,203 & 0,265 & 0,188 & 0,306 & 0,463 & 0,149 & & 0,324 & 0,326 & 0,176 \\
\hline Thck & $\mid$ & \begin{tabular}{|l|}
0,339 \\
\end{tabular} & 0,229 & 0,255 & 0,340 & 0,323 & 018 & 0,221 & 0,089 & 0,254 & 0,293 & \begin{tabular}{|l|}
0,167 \\
\end{tabular} & 0,324 & & 0,274 & 0,249 \\
\hline Hzl & 0,202 & 0,186 & 0,315 & 0,233 & 0,318 & 0,340 & 0,137 & 0,312 & 0,199 & 0,198 & 0,338 & \begin{tabular}{|l|}
0,071 \\
\end{tabular} & 0,326 & 0,274 & & 0,167 \\
\hline ShelM & \begin{tabular}{|l|}
0,163 \\
\end{tabular} & 0,247 & 0,199 & 0,177 & 0,211 & 0,202 & 0,241 & 0,173 & 0,072 & 0,271 & 0,186 & 0,165 & 0,176 & 0,249 & 0,10 & \\
\hline
\end{tabular}

\section{Research}

Our research aims at visualizing and analyzing the markeme links in literary texts of Russian and British writers of the first half of $19^{\text {th }}$ century.

The study subject is texts of 21 Russian and 16 English writers of the first half of XIX century (19-1). The works of Batyushkov (Батюшков), Baratynskiy (Баратынский), Bestuzhev-Marlinskiy (БестужевМарлинский), Venevitinov (Веневитинов), Vyazemskiy (Вяземский), Gnedich (Гнедич), Gogol (Гоголь), Griboyedov (Грибоедов), Davydov (Давыдов), Delvig (Дельвиг), Zhukovskiy (Жуковский), Zagoskin (Загоскин), Koltsov (Кольцов), Kyukhelbeker (Кюхельбекер), Lermontov (Lermontov ), Odoyevskiy (Одоевский), Pogorelskiy (Погорельский), Polevoy (Полевой), Pushkin (Пушкин), Ryleyev (Рылеев), Yazykov (Языков) were selected to study markeme links in Russian literary texts (original names of Russian writers are given in brackets). As for English literature the works of Charlotte Brontë, Ann Brontë, Edward Bulwer Lytton, Elizabeth Gaskell, Benjamin Disraeli, Isaac Disraeli, Thomas Carlyle, Thomas De Quincey, 
Samuel Taylor Coleridge, Charles Lamb, Frederick Marryat, Charles Robert Maturin, Walter Scott, William Makepeace Thackeray, William Hazlitt, Mary W. Shelley were chosen for this analysis.

The target goal needs solving the following tasks: 1 . to determine the preferred markeme links between the authors; 2 . to study substantially markeme links of maximum force; 3 . to compare the linking markemes vocabulary in Russian and English literary texts.

The determination of the preferred markeme links between the authors is done according to the largest value of IMaS in each pair of the authors. Then a graph that shows main vector links and their force for the authors is drawn. Further study is based on the analysis of those markemes that couple the authors.

According to the largest IMaS value, two graphs of preferred links for Russian and English writers respectively were drawn.

Markemes in Russian Literature of the First Half of 19 Century. Figure 1 illustrates the graph of preferred links between Russian writers of 19-1.

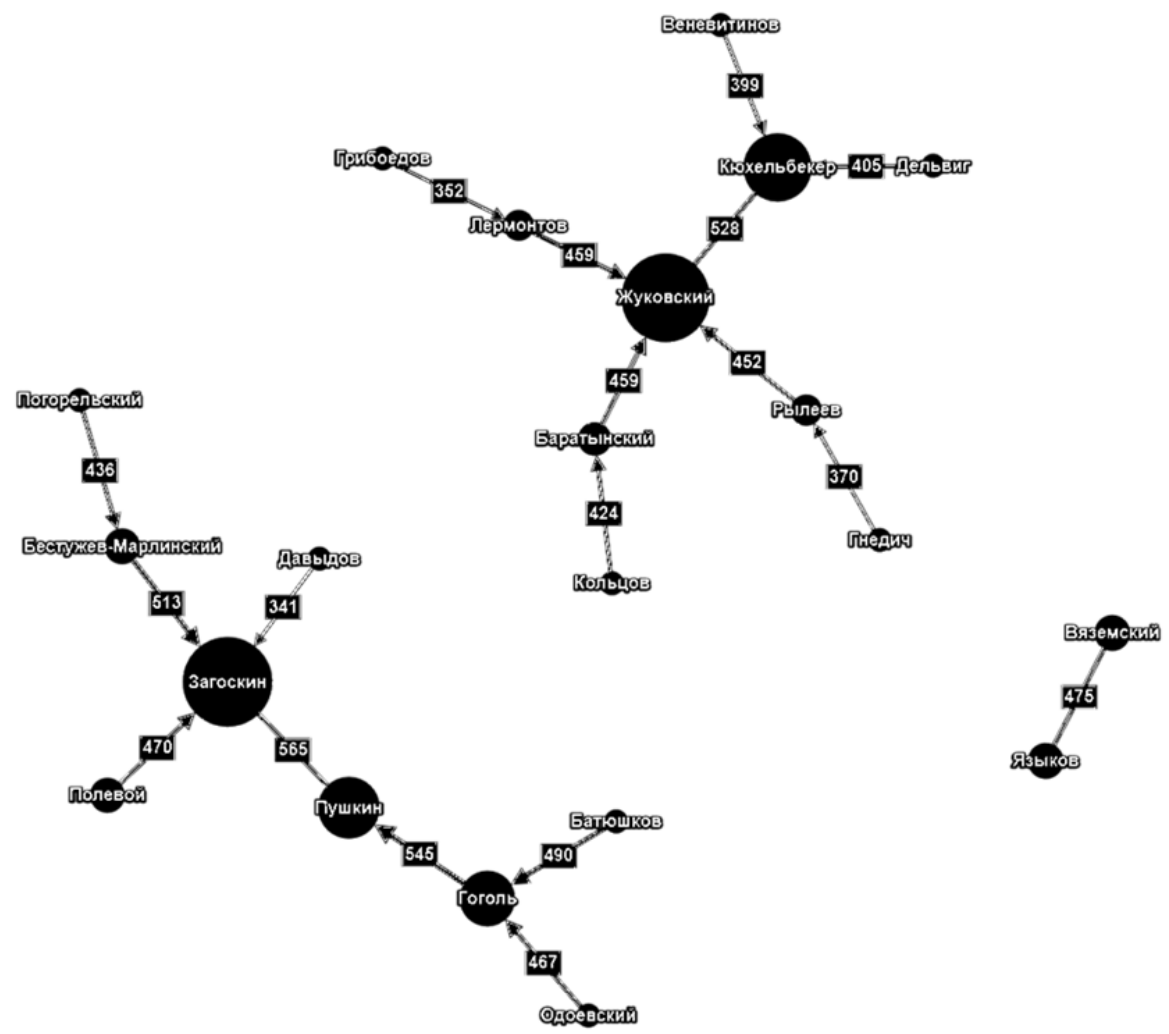

Figure 1. Graph of preferred links between Russian writers of 19-1 
Determining the links of maximum force makes possible analyzing the linking force of markemes in reference to Centers of Attraction (CA). A CA is a group of authors whose links are mutually oriented. In the graph, mutually oriented links are shown as charged non-oriented links. So, among Russian writers two large (Pushkin-Zagoskin, Zhukovskiy-Kyukhelbeker and one isolated (Vyazemskiy-Yazykov) centers of attraction could be distinguished. This provides the possibility to identify markemes, which link each author with key figures of his/her center and determine the magnitude of the linking force for each markeme of the chronological interval.

The graph illustrates that Bestuzhev-Marlinskiy, Zagoskin, Pushkin, Gogol, Brartynskiy, Lermontov, Kyukhelbeker, Zhukovskiy, Ryleyev, Vyazemskiy, Yazykov have both centrifugal and centripetal links. We consider a link as a centrifugal one when it is oriented from a given author toward the author whose IMaS is the closest. Those links that are oriented towards the CA are called centripetal in reference to this center of attraction. Those authors who have such links form Intermediate Centers (IC) - Bestuzhev-Marlinskiy, Gogol, Baratynskiy, Lermontov, Ryleyev. In the graph all the ICs are linked with CA directly, so they are called ICs of the first order (IC-1). The key figures of CA comprise the ICs of a zero order in reference to each other Zagoskin, Puskin, Kyukhelbeker, Zhukovskiy, Vyazemskiy, Yazykov. In the periphery of the graph, there are authors who have no centripetal links - Pogorelskiy, Griboyedov, Koltsov, Gnedich. We call them terminal authors (the farthest authors from IC). In the process of the analysis, we consider the principle of links and weights "inheritance". This makes possible to identify markeme links between terminal authors and CA.

To determine core and peripheral markemes we use the value of Total Weight of Markeme Link in all the pairs of authors (TotLWeight) and to determine the CA power we compute Integral Linking Weight (InLWeight) for markemes of key figures of CA. The formula for computing InLWeight is as follows:

$$
\text { InLWeight }=\text { TotLWeight } \times Q_{m},
$$

where TotLWeight - total weight of markeme links, $Q_{m}$ - the number of links the given markeme provides. The value of TotLWeight equals numerically the value of total normalized InTeM of a markeme in all the links it serves.

21 vector links of maximum force including 15 centrifugal and $6 \mathrm{mu}-$ tually oriented links connect all the writers. These links are provided with 100 markemes, the total number of their use is 428 . Their ranking in descending order of InLWeight allows determining core and peripheral markemes. InLWeight arithmetic mean value is taken as the boundary between the core and the periphery. The similar computing of the InLWeight arithmetic mean valueInLWeight for core and peripheral markemes respectively make it possible to distinguish a small and a big core among core 
markemes and a small and a big periphery among peripheral ones. Table 2 presents the data we use to visualize the core and peripheral markemes distribution based on InLWeight (Fig. 2).

Table 2

\section{Data about the core and peripheral markemes distribution}

\begin{tabular}{|c|c|c|c|c|c|c|c|}
\hline markeme & InLWeight & markeme & InLWeight & markeme & $\begin{array}{c}\text { InL } \\
\text { Weight }\end{array}$ & markeme & $\begin{array}{c}\text { InL } \\
\text { Weight }\end{array}$ \\
\hline человек & 195,824 & здоровье & 13,087 & направление & 1,61762 & красноречие & 0,43002 \\
\hline сердце & 149,945 & характер & 11,7414 & благодать & 1,52766 & потребность & 0,42612 \\
\hline чувствО & 106,691 & обязанность & 11,2366 & красота & 1,51374 & обыкновение & 0,41875 \\
\hline воображение & 96,2369 & страданье & 9,84605 & надежда & 1,2314 & преимущество & 0,33536 \\
\hline отечество & 57,0218 & провиденье & 9,02221 & спасенье & 1,23133 & погибель & 0,32526 \\
\hline внимание & 47,0942 & удовольствие & 8,61144 & звезда & 1,21787 & рассудок & 0,31909 \\
\hline спокойствие & 46,2709 & движение & 7,98296 & задумчивость & 1,19496 & восторг & 0,31637 \\
\hline счастье & 43,738 & призрак & 7,55937 & (мла/моло)дость & 1,13509 & остроумие & 0,30751 \\
\hline природа & 39,6729 & благословен(w/b)e & 7,53541 & веселость & 1,08068 & очарованье & 0,3061 \\
\hline богатство & 36,8066 & справедливость & 7,42811 & воздух & 1,03087 & разнообразие & 0,27063 \\
\hline любопытство & 35,3755 & веселье & 7,17362 & воспоминание & 1,0234 & удивление & 0,26414 \\
\hline радость & 32,8559 & самолюбие & 6,1825 & голова & 0,98842 & забвенье & 0,26373 \\
\hline молчан(и/ь)е & 30,679 & отчаяние & 6,12595 & история & 0,94308 & старость & 0,25642 \\
\hline солнце & 27,4856 & сладость & 4,9349 & невежество & 0,93233 & торжество & 0,25608 \\
\hline достоинство & 26,6412 & прелесть & 4,43421 & раскаян(и/ь)е & 0,85405 & беспокойство & 0,24426 \\
\hline добродетель & 25,9637 & любовь & 3,62808 & доверенность & 0,76594 & жребий & 0,24409 \\
\hline наслажден(и/ь)е & 24,4416 & несчастие & 3,51491 & привязанность & 0,706 & утешенье & 0,20483 \\
\hline блаженство & 22,433 & ВозМОЖНОСТь & 3,30259 & деятельность & 0,66739 & смерть & 0,19832 \\
\hline искусство & 19,0126 & состояние & 3,26772 & гостеприимство & 0,59782 & предчувствие & 0,1636 \\
\hline впечатление & 17,9606 & вдохновенье & 2,72198 & бессмертие & 0,55931 & несправедливость & 0,15397 \\
\hline благодарность & 17,2271 & человечество & 2,30969 & храбрость & 0,49763 & правда & 0,15288 \\
\hline доказательство & 16,6787 & недостаток & 2,02237 & мужество & 0,4906 & бешенство & 0,11941 \\
\hline мгновен $(и / \mathrm{b}) \mathrm{e}$ & 14,8524 & выражение & 1,98496 & образование & 0,4683 & будущность & 0,11941 \\
\hline просвещение & 14,1904 & необходимость & 1,68094 & Способность & 0,45431 & презрение & 0,11941 \\
\hline время & 14,0489 & свобода & 1,67801 & общество & 0,44472 & вЗгляд & 0,04752 \\
\hline
\end{tabular}

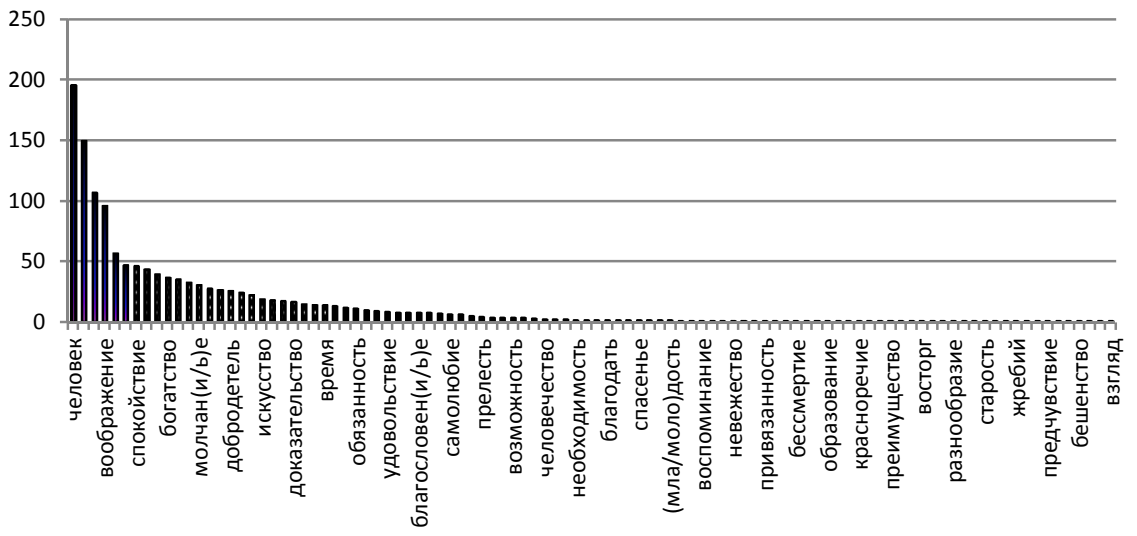

Figure 2. Distribution of core and peripheral markemes based on InLWeight 
Arithmetic mean value of InLWeight being 13.38, the core boundary is время. The number of core markemes totals 25 and peripheral markemes - 75. Six markemes человек, сердие, чувство, воображение, отечество, внимание comprise the small core. The large core includes спокойствие, счастье, природа, богатство, любопьтство, радость, молчание, солние, достоинство, добродетель, наслаждение, блаженство, искусство, впечатление, благодарность, доказательство, мгновение, просвещение, время. Peripheral markemes distribute unevenly as well. The small periphery is composed of 20 markemes and the large periphery is composed of 55 markemes. The small periphery includes здоровье, характер, обязанность, страданье, провиденье, удовольствие, движение, призрак, благословение, справедливость, веселье, самолюбие, отчаяние, сладость, прелесть, любовь, несчастие, возможность, состояние, вдохновенье. The large periphery consists of человечество, недостаток, выражение, необходимость, свобода, направление, благодать, красота, надежда, спасенье, звезда, задумчивость, молодость, веселость, воздух, воспоминание, голова, история, невежество, раскаяние, доверенность, привязанность, деятельность, гостеприимство, бессмертие, храбрость, мужество, образование, способность, общество, красноречие, потребность, обыкновение, преимущество, погибель, рассудок, восторг, остроумие, очарованье, разнообразие, удивление, забвенье, старость, торжество, беспокойство, жребий, утешенье, смерть, предчувствие, несправедливость, правда, бешенство, будущность, презрение, взгляд.

Markeme analysis of all centripetal links between CA and ICs-1 enables studying bilateral markeme links between key figures of CA, identifying linking markemes and determining markeme specificity of each center.

The first CA (CA-1) unites prosaic writers who group near two key figures of CA-1 Zagoskin and Pushkin and have no markeme links of maximum force between themselves. As Pushkin and Zagoskin constitute ICs-0 in reference to each other, the markeme specificity of IC-0 Zagoskin and that of IC-0 Pushkin were studied. The number of linking markemes in each IC-0 is 25 . IC-0 Zagoskin includes 22 passing through markemes and 3 outgoing ones. As for IC-0 Pushkin, it includes 18 passing through markemes and 7 outgoing ones.

Centrifugal links from Pushkin, Davydov, Polevoy, and IC-1 Bestuzhev-Marlinskiy form IC-0 Zagoskin. That IC-1 Bestuzhev-Marlinskiy mediates the link between a terminal author Pogorelskiy and Zagoskin.

Centrifugal links from Zagoskin, Batyushkov, Odoyevskiy and IC-1 Gogol form IC-0 Pushkin. IC-1 Gogol mediates the links between terminal authors Batyushkov, Odoyevskiy, and Pushkin.

The difference between InLWeight of each IC-0 markemes is a method to determine the specificity of IC- 0 . In this case, a positive differ- 
ence specifies IC-0 Zagoskin and a negative difference specifies IC-0 Pushkin (Fig. 3).

\section{Zagoskin - Pushkin}

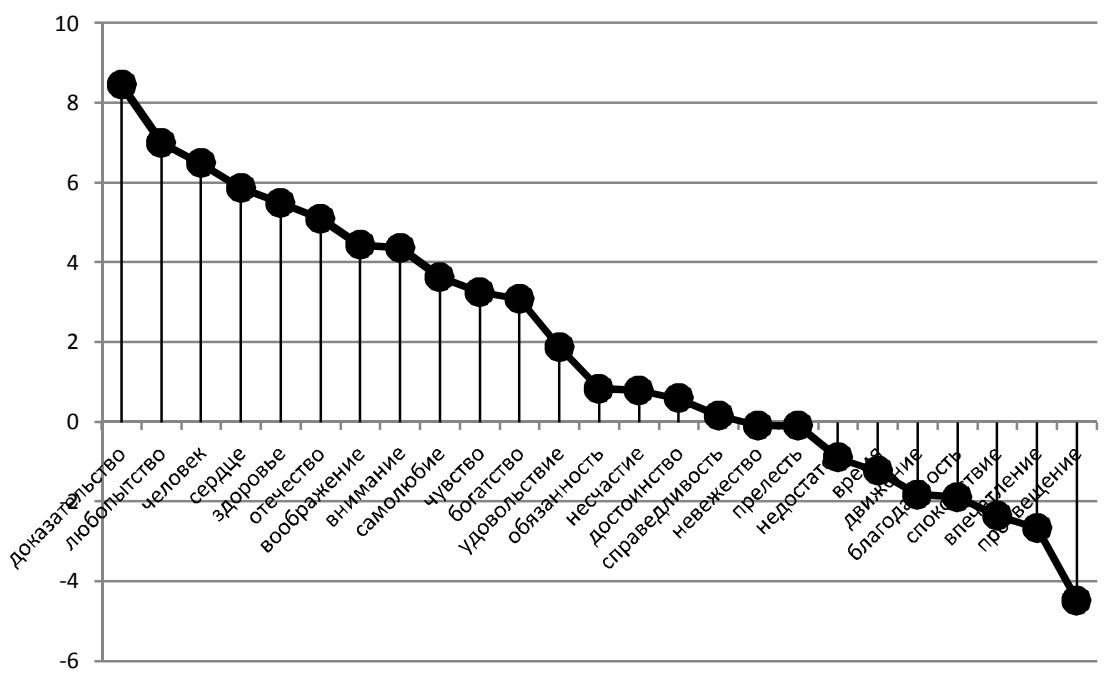

Figure 3. Markeme specificity of IC-0 Zagoskin and IC-0 Puskin

The core markemes of IC-0 Zagoskin доказательство, любопьтство, человек, сердие, здоровье, отечество, воображение, внимание and markemes of his small periphery самолюбие, чувство, богатство, удовольствие determine the specificity this IC-0. The remainder of IC-0 Zagoskin specific markemes InLWeight ranges from 1.87 to 8.45. The core markemes of IC-0 Pushkin просвещение, впечатление, спокойствие, благодарность, движение determine the specificity of the $\mathrm{IC}-0$. The remainder of IC-0 Pushkin specific markemes InLWeight ranges from 1.83 to 4.48. The remainder of other markemes is below mean InLWeight difference of markemes and does not essentially specify any of the IC-0 considered.

To determine a markeme specificity of CA-1 Zagoskin-Pushkin, we ranked markemes of both ICs-0 due to their summarized InLWeight (Fig. 4).

The core markemes of CA-1 include all core markemes of IC-0 Zagoskin and five core markemes of IC-0 Pushkin. The dominant markeme is a small core markeme of two ICs-0 человек. The vice-dominant markeme is a small core markeme of IC-0 Zagoskin любопьтство. The core markemes of two ICs-0 воображение, внимание also became core markemes of CA-1. The core markemes of IC-0 Pushkin достоинство, благодарность, впечатление, спокойствие passed into the category of the small periphery and просвещение, движение passed into the category of the 
large periphery. As noted the change in a markeme status influenced only the markemes of IC-0 Pushkin. Thus, we can conclude that the body of CA-1 core markemes is mainly composed of the core markemes of IC-0 Zagoskin, and the body of the peripheral markemes is mainly composed of the peripheral markemes of IC-0 Pushkin.

\section{Zagoskin + Pushkin}

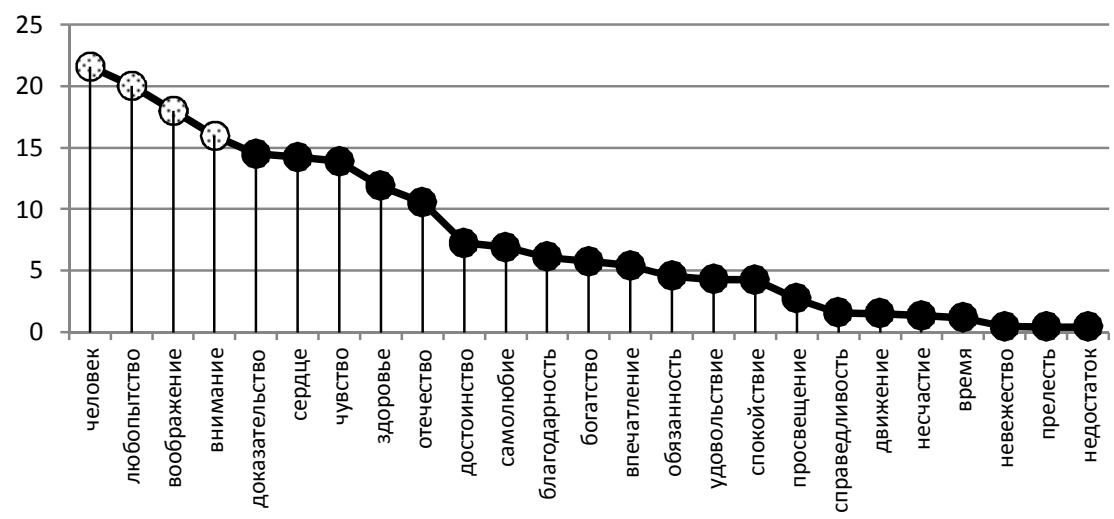

Figure 4. Markeme specificity of CA-1 Zagoskin-Pushkin

As two poets Zhukovskiy and Kyukhelbeker have mutually oriented links, they form CA-2. They have 24 linking markemes. Their common markemes are человек, сердие. The exclusive markemes of the pair Zhukovskiy-Kyukhelbeker are благословенье, спасенье.

IC-0 Kyukhelbeker includes 16 passing through and 8 outgoing markemes. The number of the core markemes is 11 . Consequently, the number of core markemes tops $46 \%$ and that of the peripheral ones tops $56 \%$.

IC-0 Zhukovskiy consists of three ICs-1Lermontov, Baratynskiy, Ryleyev. Those ICs-1 mediate the link between Griboyedov, Koltsov, Gnedich, and Zhukovskiy. IC-0 Zhukovskiy includes 22 passing through and 2 outgoing markemes. Ten markemes comprise the core and 14 markemes refer to the periphery. The number of the core markemes tops $42 \%$ and that of the peripheral ones tops $58 \%$. The proportion of the small (4 markemes $40 \%$ ) and the large (6 markemes - 60\%) core markemes, the small (6 markemes - 43\%) and the large ( 8 markemes - 57\%) peripheral markemes are practically the same.

Сердие, человек, богатство, блаженство, счастье, солние, молчанье, добродетель are specific core markemes of IC-0 Zhukovskiy. Природа, страданье, провиденье, радость, отечество, мгновенье are its small periphery specific markemes. Those markemes InLWeight remainder falls within 1.09-14.78. InLWeight remainder being 1.66, an IC-0 Kyukhel- 
beker core markeme спокойствие specifies that IC-0 (Fig. 5). InLWeight remainder of the markemes искусство, чувство, призрак, вдохновенье, спасенье, благословенье, наслажденье, воображение, характер falls within $0.17-0.95$ and does not essentially specify any of the IC-0 considered.

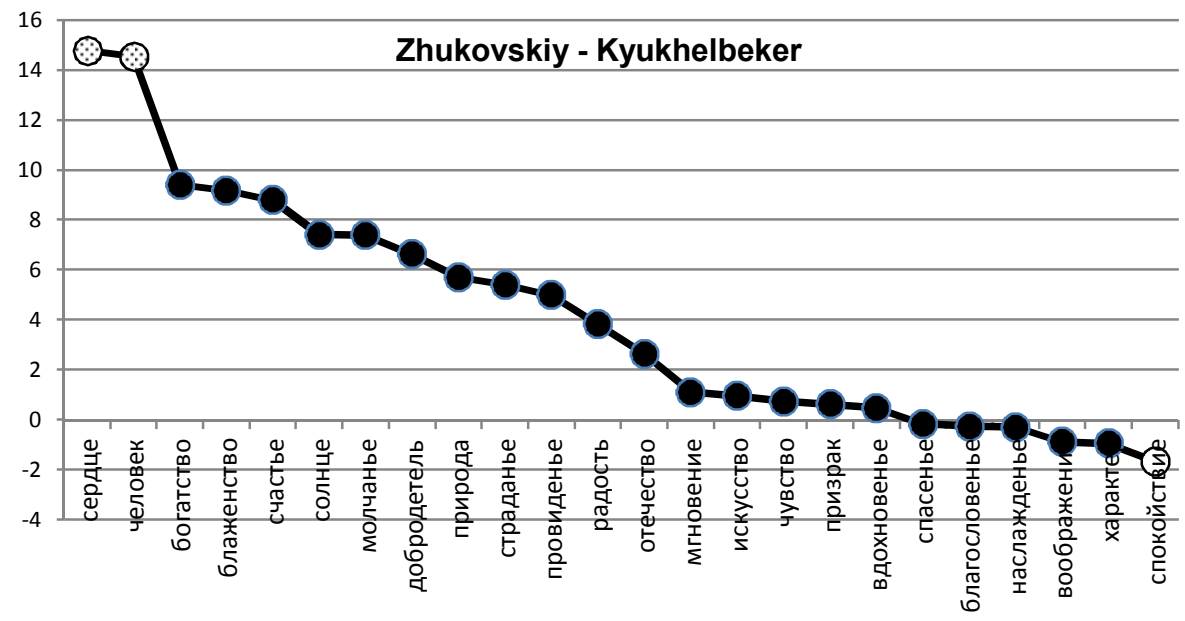

Figure 5. Markeme specificity of IC-0 Zhukovskiy and IC-0 Kyukhelbeker

Markemes of IC-0 Zhukovskiy and IC-0 Kyukhelbeker ranked in descending order of their summarized InLWeight specify CA-2 ZhukovskiyKyukhelbeker (Fig. 6).

The core markemes of CA- 2 include all the core markemes of IC-0 Zhukovskiy and seven core markemes of IC-0 Kyukhelbeker. The dominant markeme is человек. It is a small core markeme of the two IC-0. Another markeme of that kind cepdue is a vice-dominant markeme. Two more core markemes of the two IC-0 счастье, блаженство entered into the small core of CA-2. Such core markemes of IC-0 Kyukhelbeker as воображение, отечество, спокойствие passed into the category of the small periphery and характер became a markeme of the large periphery. The status change touches mainly the markemes of IC- 0 Kyukhelbeker. Alongside with its core markemes that became the peripheral markemes, four peripheral markemes became the core markemes. These are small peripheral markemes солние, природа, and large peripheral markemes богатство, молчанье that entered into the core markemes of CA-2. Besides, we registered the redistribution of the markemes only within the peripheral markemes. Thus, we can conclude that markemes of IC- 0 Zhukovskiy determined mainly the composition of the core and peripheral markemes of CA-2.

The mutual markemes of Vyazemskiy and Yazykov specify isolated CA Vyazemskiy-Yazykov. The markeme body includes 10 core and 11 peripheral markemes. The markemes человек, свобода, сердие, природа con- 
stitute the small core and благодать, красота, счастье, радость, прелесть, сладость are large core markemes.

\section{Zhukovskiy + Kyukhelbeker}

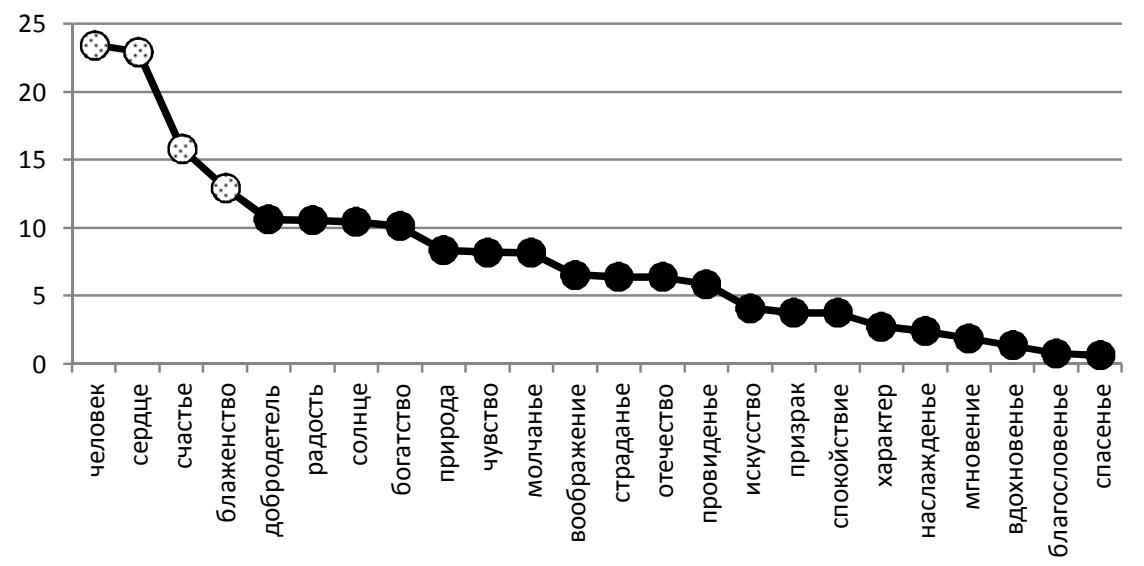

Figure 6. Markeme specificity of CA-2 Zhukovskiy-Kyukhelbeker

There is a link between three CA at the level of individual markemes (Fig. 7).

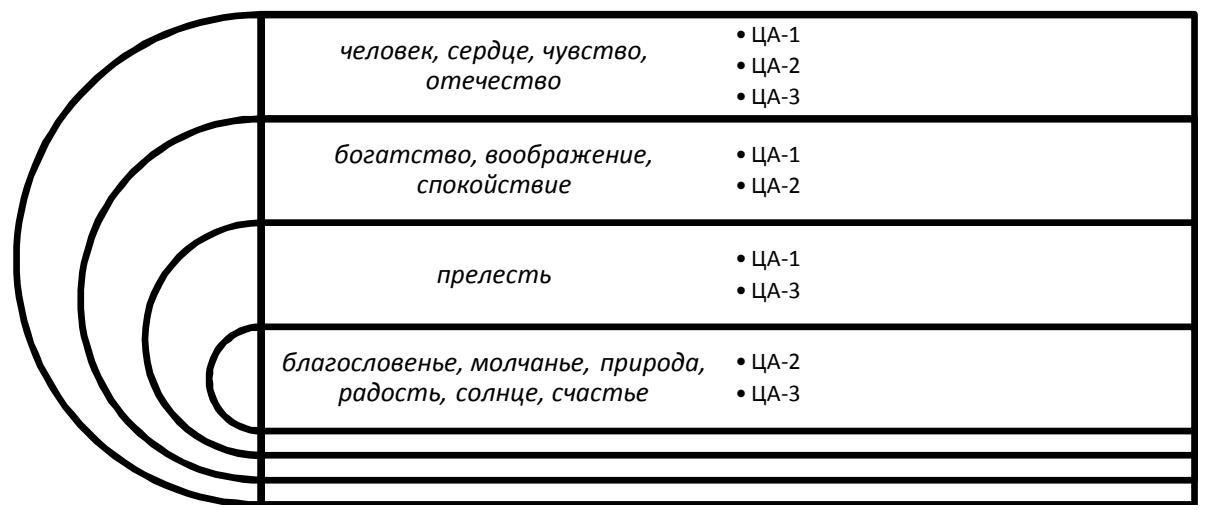

Figure 7. Markemes that link all CA

Hence, 7 markemes link CA-1 Zagoskin-Pushkin and CA-2 Zhukovskiy-Kyukhelbeker, 5 markemes link CA-1 Zagoskin-Pushkin and CA-3 Vyazemskiy-Yazykov. CA-3 Vyazemskiy-Yazykov in its turn has 10 common markemes with CA-2. Thus in spite the fact that there is no direct link of maximum force between centers of attraction there is an indirect 
link at the level of individual markemes. These markemes distribute the following way: CA-1 - 5 core markemes, including 2 small core markemes, and 3 peripheral markemes, including 2 small periphery markemes; CA-2 9 core markemes, including 3 small core markemes, and 4 peripheral markemes, including 3 small periphery markemes; CA-3 - 6 core markemes, including 3 small core markemes, and 5 peripheral markemes, including 2 small periphery markemes.

Thus, the analysis reveals that

1. In 19-1 the dominant linking markeme is человек. It is also a dominant linking markeme in each CA. The vice-dominant linking markeme is сердие. It is a vice-dominant markeme of CA-2 represented by two poets Zhukovskiy and Kyukhelbeker.

2 . The core markemes body of CA-1 fully agrees with the core markeme body of CA- 2 . The core markemes body of CA-3 tops $50 \%$ of the core markeme body of CA-2.

3. Emotional and mental markemes, markemes that denote personality traits, ideals, values, and rules dominate among linking markemes. There are also markemes that deal with a person as a human and with his physique, nature-made objects and natural phenomena, and relate to philosophical categories.

Markemes in English Literature of the First Half of 19 Century. Figure 10 illustrates the graph of preferred links between English writers of 19-1.

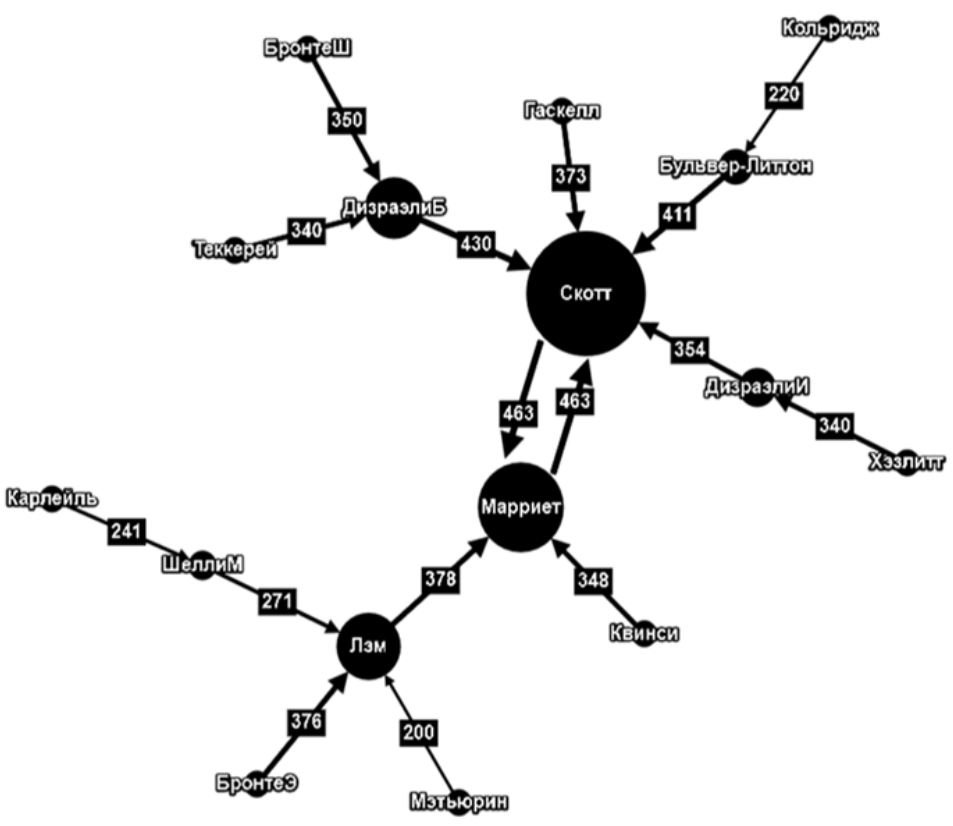

Figure 8. Graph of preferred links between English authors 
16 vector links of maximum force including 14 centrifugal and $2 \mathrm{mu}-$ tually oriented links link all the writers. These links are provided with 86 markemes, the total number of their use is 410 . Table 4 presents the data we use to visualize the core and peripheral markemes distribution based on InLWeight (Fig. 9).

Table 4

Data on the core and peripheral markemes distribution

\begin{tabular}{|c|c|c|c|c|c|}
\hline маркема & ИнСBec & маркема & ИнCBec & маркема & ИнСBec \\
\hline DISAPPOINTMENT & 5,94373 & INTERFERENCE & 0,41262 & IMPOSSIBILITY & 0,02277 \\
\hline CONSCIOUSNESS & 5,84963 & DISINTERESTEDNESS & 0,38174 & LICENTIOUSNESS & 0,02191 \\
\hline CONSIDERATION & 5,67069 & RESPECTABILITY & 0,34565 & EXTRAVAGANCE & 0,02161 \\
\hline DIFFICULT(Y/IES) & 5,23688 & ACCOMPLISHMENT & 0,30857 & COMPREHENSION & 0,01925 \\
\hline UNDERSTANDING & 4,91921 & SUPERSTITION & 0,29341 & COMPANIONSHIP & 0,01895 \\
\hline RECOLLECTION & 4,31351 & CONSCIENCE & 0,27838 & ANTICIPATION & 0,01836 \\
\hline SATISFACTION & 3,93239 & INSENSIBILITY & 0,25272 & SELF-CONGRATULATION & 0,01829 \\
\hline IMAGINATION & 3,85891 & EMBARRASSMENT & 0,22192 & IMPROVEMENT & 0,01820 \\
\hline CONTEMPLATION & 3,62375 & CONSTERNATION & 0,21318 & SENSIBILITY & 0,01741 \\
\hline OPPORTUNITY & 3,34506 & CONTRADICTION & 0,20339 & LITY & 0,01724 \\
\hline INDIFFERENCE & 2,95729 & CONDESCENSION & 0,16727 & ITURE & 0,01717 \\
\hline RECONCILIATION & 2,87137 & ADMIRATION & 0,15924 & ANNIHILATION & 0,01695 \\
\hline ASTONISHMENT & 2,60912 & EXPERIENCE & 0,14938 & UNWILLINGNESS & 0,01604 \\
\hline ACKNOWLEDG(E)MENT & 2,43351 & MAGNIFICENCE & 0,14876 & SPECULATION & 0,01587 \\
\hline DETERMINATION & 2,30543 & HOSPITALITY & 0,14214 & ENTHUSIASM & 0,01555 \\
\hline ENCOURAGEMENT & 2,12108 & EXISTENCE & 0,14099 & SITY & 0,01547 \\
\hline MORTIFICATION & 1,74687 & FRIENDSHIP & 0,13644 & ROPHE & 0,01528 \\
\hline RESPONSIBILITY & 1,74311 & TRANQUILLITY & 0,10167 & INCONVENIENCE & 0,01508 \\
\hline GRATIFICATION & 1,66775 & SELF-POSSESSION & 0,08570 & INSIGNIFICANCE & 0,01492 \\
\hline CONFIDENCE & 1,64980 & SELF-COMPLACENCY & 0,08430 & SIMPLICITY & 0,01467 \\
\hline INDEPENDENCE & 1,48573 & EXCITEMENT & 0,06511 & KNOWLEDGE & 0,01427 \\
\hline INDIGNA & 1,42911 & CONSOLATION & 0,06436 & $\mathrm{CON}$ & 0,01415 \\
\hline OBSERVA & 1,17183 & REMEMBRANCE & 0,06408 & TION & 0,01368 \\
\hline DISSATISFACTION & 1,11759 & AFFECTION & 0,05978 & CARELESSNESS & 0,01348 \\
\hline INTELLIGENCE & 0,95521 & TENDERNESS & 0,05973 & EXPECTATION & 0,01262 \\
\hline DESTRUCTION & 0,88289 & ASSISTANCE & 0,05048 & MISFORTUNE & 0,01229 \\
\hline RESOLUTION & 0,78147 & CONTRADISTINCTION & 0,03790 & PLEASURE & 0,01191 \\
\hline MISUNDERS & 0,71440 & DISCRIMINATION & 0,02797 & FELLOW-CREATURE & 0,01092 \\
\hline SELF-PRESERVATION & 0,54637 & MISREPRESENTATION & 0,02286 & & \\
\hline
\end{tabular}

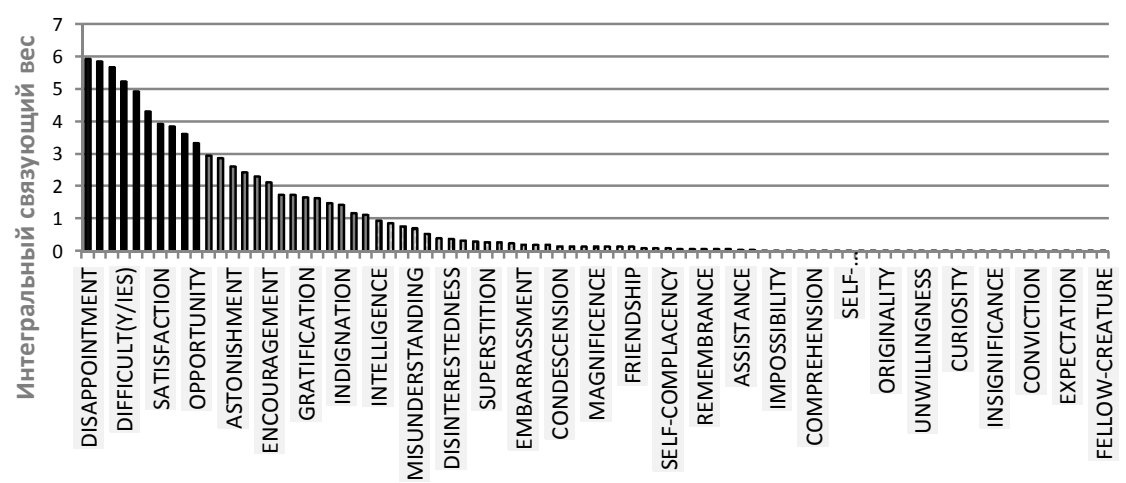

Figure 9. Distribution of the core and peripheral markemes based on InLWeight 
InLWeight arithmetic mean value is 0.97 , the core boundary is dissatisfaction. The markemes disappointment, consciousness, consideration, difficult(y/ies), understanding, recollection, satisfaction, imagination, contemplation, opportunity comprise the small core. The large core includes 14 markemes indifference, reconciliation, astonishment, acknowledgment, determination, encouragement, mortification, responsibility, gratification, confidence, independence, indignation, observation, dissatisfaction. The number of the core markemes totals 24 and the peripheral markemes - 62 .

As the graph shows there is one CA Scott-Marryat, four ICs-1 - Lamb, Benjamin, and Isaac Disraeli, Bulwer Lytton, and IC-2 Mary Shelley. Terminal authors are Maturin, Charlotte Brontë, Ann Brontë, Carlyle, Thackeray, Coleridge, and Hazlitt.

The centrifugal links from Marryat, Gaskell and 3 IC-1 B. Disraeli, I. Disraeli, Bulwer Lytton form IC-0 Scott. Those ICs-1 mediate the links between Scott and terminal authors Thackeray, Charlotte Brontë, Coleridge, Hazlitt. IC-0 Scott includes 40 passing through markemes and 3 outgoing ones.

The centrifugal links from Scott, De Quincey, and IC-1 Lamb form IC-0 Marryat. IC-1 Lamb mediates the links between Marryat and Ann Brontë, Maturin and Mary Shelley. At the same time, IC-2 Mary Shelley mediates the link between Carlyle and Lamb and from Lamb with Marryat. IC-0 Marryat includes 38 passing through markemes and 4 outgoing ones.

When determining the markeme specificity of ICs-0 Scott and Marryat we distinguish 2 cores (Fig. 10).

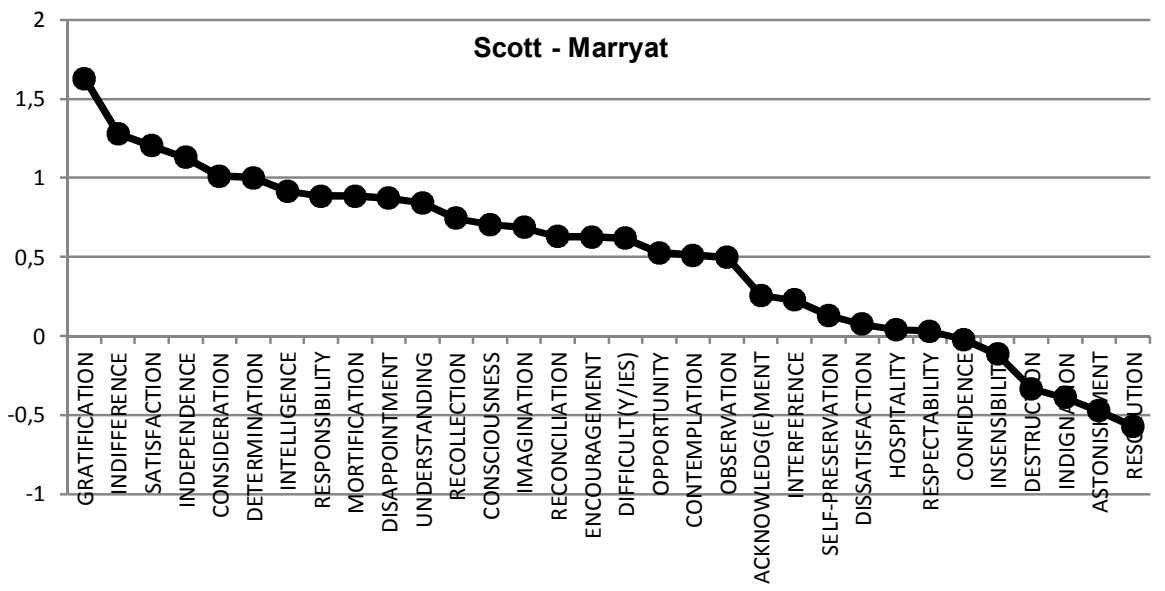

Figure 10. Markeme specificity of IC-0 Scott and IC-0 Marryat

The number of the core markemes in IC-0 Scott (core 1) is 13, the first five of them constitute the small core. The number of the core markemes in IC-0 Marryat (core 2) is 4. They specify IC-0 Marryat. The 
markemes gratification, indifference, satisfaction, independence, consideration, determination, intelligence, responsibility, mortification, disappointment, understanding, recollection, consciousness constitute core 1. In spite the fact that the core 1 markemes characterize the centripetal links of the two IC- 0 , the InLWeight values of these markemes in IC-0 Scott exceed the similar values in IC-0 Marryat minimum in 1.5 (consciousness), and maximum in 75 (gratification) times. Minimum InLWeight remainder characterizes the large peripheral markemes of IC-0 Scott and all peripheral markemes of IC-0 Marryat - acknowledg(e)ment, interference, selfpreservation, dissatisfaction, hospitality, respectability, confidence, insensibility. For the markemes in IC-0 Scott, the InLWeight remainder ranges from 0.03 to 0.26 , in IC-0 Marryat the remainder ranges from 0.02 to 0.11 . Therefore, we consider them relatively equivalent markemes that do not essentially specify any of the IC-0 considered. Thus, the core 2 markemes destruction, indignation, astonishment, resolution with the InLWeight remainder 0.33-0.57 specify IC-0 Marryat. Listed above the core 1 markemes and the small periphery markemes of IC-0 Scott imagination, reconciliation, encouragement, difficult(y/ies), opportunity, contemplation, observation specify IC-0 Scott. Their InLWeight remainder ranges from 0.5 to 1.63 .

32 markemes ranked in descending order of their summarized InLWeight are linking markemes of CA Scott-Marryat (Fig. 11).

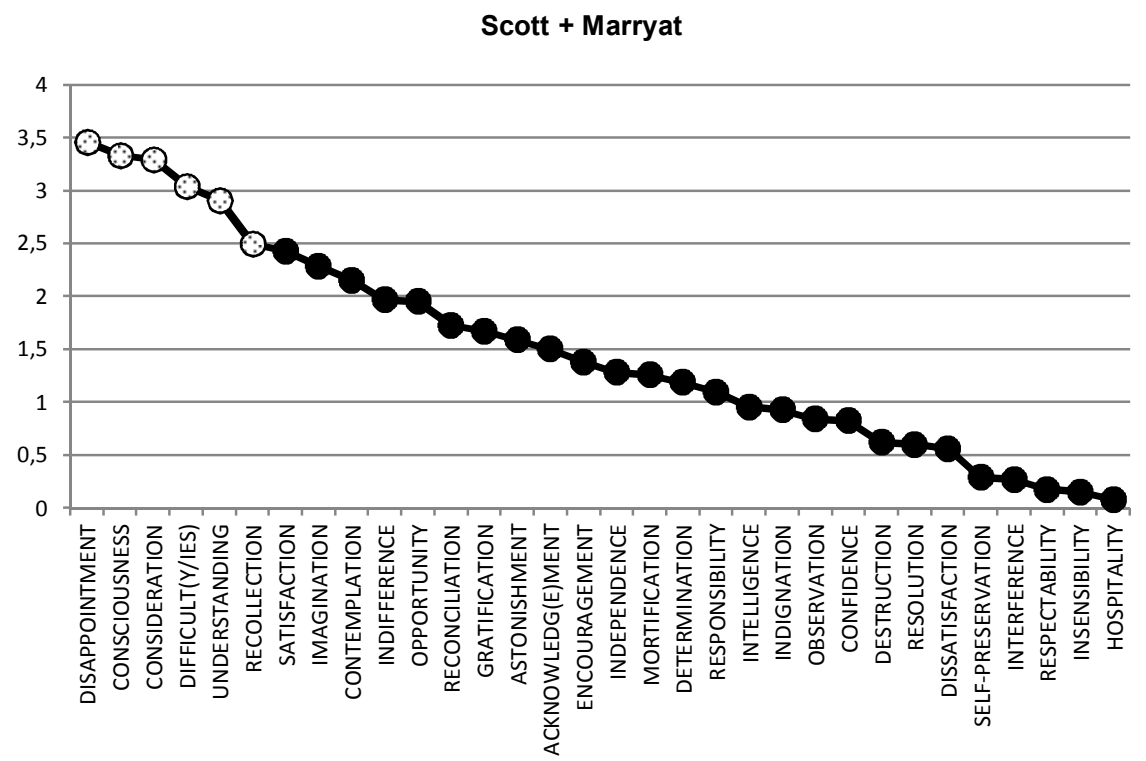

Figure 11. Markeme specificity of CA Scott-Marryat

Core markemes of CA include 13 core markemes of IC-0 Scott and 12 core markemes of IC-0 Marryat. Small core markemes of two IC-0 con- 
stitute a small core of CA. The dominant markeme is a dominant markeme of IC-0 Scott disappointment. The vice-dominant markeme is a dominant markeme of IC-0 Marryat consciousness. Astonishment, which is a small periphery markeme of IC-0 Scott, became the large core markeme. The reason is that astonishment is a small core markeme of IC-0 Marryat. As for gratification, the situation is similar. In IC-0 Scott it is a small core markeme and in IC-0 Marryat it is a large periphery markeme, but in CA it is already a large core markeme. The number of the core and peripheral markemes in CA decreased due to the decrease in the total number of CA markemes (32) as compared to the number of the markemes in IC-0 Scott (42) and IC-0 Marryat (42). Therefore, such large core markemes of IC-0 Scott as acknowledg(e)ment, encouragement, independence, mortification, determination, responsibility, intelligence have come into the small periphery markemes in CA. Their status in CA has changed because all the markemes but one acknowledg(e)ment belong to the small (encouragement, mortification) and the large (independence, determination, responsibility, intelligence) periphery in IC-0 Marryat. Two large core markemes of IC-0 Marryat indignation, confidence has become the small periphery markemes of CA as well. Among the markemes that constitute the large periphery of CA alongside with two small periphery markemes of IC-0 Scott dissatisfaction, interference, two large core markemes destruction, resolution and two small periphery markemes dissatisfaction, insensibility of IC-0 Marryat have changed their status. Thus, we can conclude that the rise of markeme status in CA touched mostly the markemes of IC-0 Marryat.

The Specificity of Markeme Vocabulary in Russian and British Literary Texts. The markeme semantic classification enables determining the specificity of markeme vocabulary in literary texts and arranging information for comparative and typological analysis of language and literary processes. Based on the markeme classification proposed by A.V. Kashkina [47] we distinguished 3 basic semantic groups of markemes - abstract, anthropological, natural fact. Figure 12 illustrates the relative weight (in \%) of these markeme groups in Russian and British literary texts.

Markemes of all the three basic semantic groups characterize Russian texts. There are no markemes of semantic group 'natural fact', which includes markemes that denote natural phenomena, celestial bodies, flora, naturally occurring materials, landscape elements, in English texts. We can suggest that this results from the fact that Russian texts include both prosaic and poetic texts. There are no poetic texts in analyzed English texts. In Russian and English texts, the markemes of 'anthropological' group predominate. Their relative weight is $11.4 \%$ higher in English texts than in Russian ones. Poetic texts could influence $7.4 \%$ exceedance of the relative weight of 'abstract' markemes in Russian literary texts. 


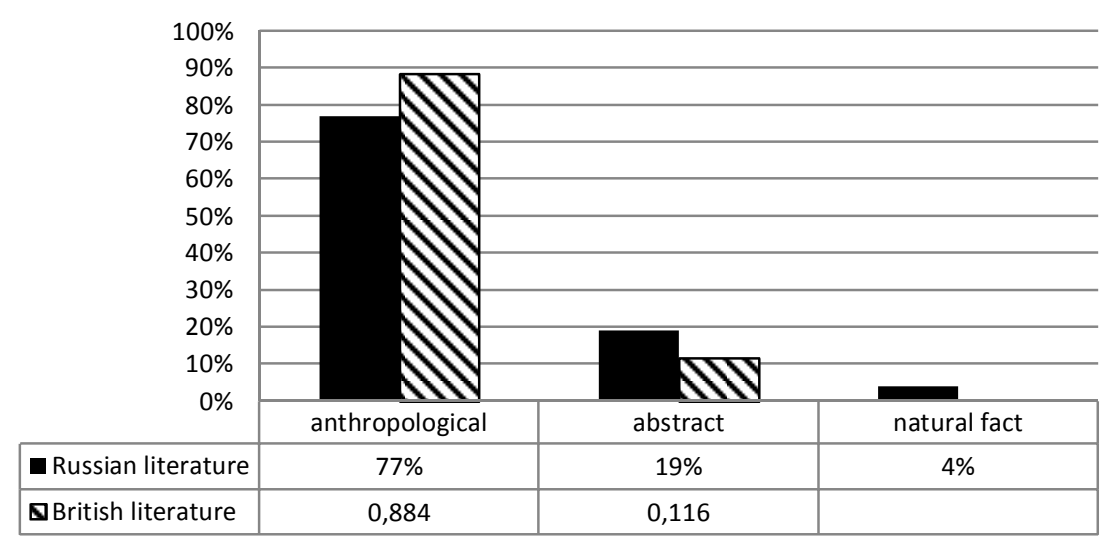

Figure 12. The relative weight of basic markeme groups

'Anthropological' group includes markemes that characterize a person. This group can be further divided into several categories. These are 'corporal' (words that describe person's appearance, physique, and age), 'personal' (words that characterize the inward man), 'social' (words that characterize a person's interaction with other people and the society). The category of 'personal' markemes includes such markeme subcategories as 'emotional' (describes person's emotions), 'mental' (connected with person's intelligence and mental activity), 'intrinsic' (describes personal qualities and a person's character). The category of 'social' markemes includes the following subcategories: 'values' (moral, religious, aesthetic, philosophical beliefs), 'interpersonal dealings' (communicative, physical, psychological), 'purely social' (the structure of the society, social problems, social and religious relationships, circumstances, an activity, an assessment of an event or a state and so on). The group of 'abstract' markemes includes the categories of 'fundamental' and 'qualitative' markemes. The most generalized basic notions connected with a knowledge system of fundamental concepts, principles, and basis of human existence constitute the category of 'fundamental' markemes. In our study 'space' markemes движение, пространство form the category of 'qualitative' markemes.

Table 5 illustrates the composition of semantic groups according to the categories and subcategories.

Table 6 presents quantity distribution of markemes throughout the semantic groups according to the categories and subcategories in Russian and English texts.

For further comparison of the semantic groups of markemes, the relative weight (in \%) of each group considering categories and subcategories was computed. The total number of linking markemes in Russian and English texts separately is taken as $100 \%$. 
Table 5

\begin{tabular}{|c|c|c|c|c|}
\hline Group & Category & Subcategory & Russian texts & English texts \\
\hline \multirow{6}{*}{ Anthropological } & \multirow{3}{*}{ Personal } & Emotional & $\begin{array}{l}\text { благодарность, } \\
\text { благодать, блажен- } \\
\text { ство, веселость, } \\
\text { веселье, восторг, } \\
\text { надежда, насла- } \\
\text { жден(и/ь)е, отчая- } \\
\text { ние, презрение, } \\
\text { радость, раска- } \\
\text { ян(и/ь)е, сердце, } \\
\text { сладость, спокой- } \\
\text { ствие, страданье, } \\
\text { счастье, удивление, } \\
\text { удовольствие, } \\
\text { чувство }\end{array}$ & $\begin{array}{l}\text { acknowledge(e)ment } \\
\text { admiration, astonish- } \\
\text { ment, consternation, } \\
\text { disappointment, dis- } \\
\text { comfiture, embarrass- } \\
\text { ment, enthusiasm, } \\
\text { excitement, dissatis- } \\
\text { faction, gratification, } \\
\text { indifference, indigna- } \\
\text { tion, insensibility, } \\
\text { mortification, satisfac- } \\
\text { tion }\end{array}$ \\
\hline & & Mental & $\begin{array}{l}\text { вдохновенье, } \\
\text { взгляд, внимание, } \\
\text { воображение, вос- } \\
\text { поминание, впечат- } \\
\text { ление, доверен- } \\
\text { ность, забвенье, } \\
\text { задумчивость, } \\
\text { очарованье, пред- } \\
\text { чувствие, рассудок, } \\
\text { состояние, способ- } \\
\text { ность }\end{array}$ & $\begin{array}{l}\text { anticipation, attention, } \\
\text { comprehension, confi- } \\
\text { dence, conscience, } \\
\text { consciousness, consid- } \\
\text { eration, contemplation, } \\
\text { conviction, curiosity, } \\
\text { discrimination, expecta- } \\
\text { tion, imagination, intelli- } \\
\text { gence, misrepresenta- } \\
\text { tion, observation, pleas- } \\
\text { ure, recollection, re- } \\
\text { membrance, specula- } \\
\text { tion, superstition, under- } \\
\text { standing, unwillingness }\end{array}$ \\
\hline & & Intrinsic & $\begin{array}{l}\text { достоинство, крас- } \\
\text { норечие, любопыт- } \\
\text { ство, мужество, } \\
\text { невежество, недо- } \\
\text { статок, обыкнове- } \\
\text { ние, обязанность, } \\
\text { остроумие, самолю- } \\
\text { бие, характер, храб- } \\
\text { рость }\end{array}$ & $\begin{array}{l}\text { carelessness, deter- } \\
\text { mination, disinterest- } \\
\text { edness, responsibility, } \\
\text { resolution, self- } \\
\text { complacency, self- } \\
\text { congratulation, self- } \\
\text { possession, self- } \\
\text { preservation, sensibil- } \\
\text { ity, simplicity, tender- } \\
\text { ness, tranquility }\end{array}$ \\
\hline & \multirow[b]{3}{*}{ Social } & Values & $\begin{array}{l}\text { добродетель, искус- } \\
\text { ство, красота, не-- } \\
\text { справедливость, } \\
\text { правда, прелесть, } \\
\text { свобода, справед- } \\
\text { ливость }\end{array}$ & licentiuosness \\
\hline & & Mystical & призрак & \\
\hline & & Interpersonal dealings & $\begin{array}{l}\text { выражение, мол- } \\
\text { чан(и/ь)е, благосло- } \\
\text { вен(и/ь)е, гостепри- } \\
\text { имство, деятель- } \\
\text { ность, любовь, } \\
\text { привязанность, } \\
\text { утешенье }\end{array}$ & $\begin{array}{l}\text { affection, assistance, } \\
\text { companionship, } \\
\text { condescension, conso- } \\
\text { lation, contradiction, } \\
\text { contradistinction, } \\
\text { encouragement, } \\
\text { friendship, hospitality, } \\
\text { inconvenience, inter- } \\
\text { ference, misunder- } \\
\text { standing, reconciliation }\end{array}$ \\
\hline
\end{tabular}




\begin{tabular}{|c|c|c|c|c|}
\hline Group & Category & Subcategory & Russian texts & English texts \\
\hline & & Purely social & $\begin{array}{l}\text { богатство, история, } \\
\text { несчастие, образо- } \\
\text { вание, отечество, } \\
\text { общество, просве- } \\
\text { щение, торжество }\end{array}$ & $\begin{array}{l}\text { accomplishment, } \\
\text { catastrophe, extrava- } \\
\text { gance, improvement, } \\
\text { insignificance, magnif- } \\
\text { icence, misfortune, } \\
\text { originality, respectabil- } \\
\text { ity }\end{array}$ \\
\hline & Corporal & & $\begin{array}{l}\text { голова, здоровье, } \\
\text { (мла/моло)дость, } \\
\text { старость } \\
\end{array}$ & \\
\hline \multirow[t]{2}{*}{ Abstract } & Fundamental & & $\begin{array}{l}\text { бессмертие, будущ- } \\
\text { ность, возможность, } \\
\text { время, доказатель- } \\
\text { ство, жребий, мгно- } \\
\text { вен(и/ь)е, необхо- } \\
\text { димость, погибель, } \\
\text { потребность, пре- } \\
\text { имущество, прови- } \\
\text { денье, разнообра- } \\
\text { зие, смерть, спасе- } \\
\text { нье, человек, чело- } \\
\text { вечество }\end{array}$ & $\begin{array}{l}\text { annihilation, destruc- } \\
\text { tion, difficult(ylies), } \\
\text { existence, experience, } \\
\text { fellow-creature, inde- } \\
\text { pendence, impossibil- } \\
\text { ity, knowledge, oppor- } \\
\text { tunity }\end{array}$ \\
\hline & Qualitative & Space & $\begin{array}{l}\text { движение, направ- } \\
\text { ление }\end{array}$ & \\
\hline Natural fact & & & $\begin{array}{l}\text { воздух, звезда, } \\
\text { природа, солнце }\end{array}$ & \\
\hline
\end{tabular}

Table 6

Quantity distribution of markemes throughout semantic groups

\begin{tabular}{|c|c|c|c|c|}
\hline Group & Category & Subcategory & Russian texts & English texts \\
\hline \multirow[t]{8}{*}{ Anthropological } & \multirow[t]{3}{*}{ Personal } & Emotional & 22 & 16 \\
\hline & & Mental & 14 & 23 \\
\hline & & Intrinsic & 12 & 13 \\
\hline & \multirow[t]{4}{*}{ Social } & Values & 8 & 1 \\
\hline & & Mystical & 1 & - \\
\hline & & Interpersonal dealings & 8 & 14 \\
\hline & & Purely social & 8 & 9 \\
\hline & Corporal & & 4 & - \\
\hline \multirow[t]{2}{*}{ Abstract } & Fundamental & & 17 & 10 \\
\hline & Qualitative & Space & 2 & - \\
\hline Natural fact & & & 4 & - \\
\hline Total markemes: & & & 100 & 86 \\
\hline
\end{tabular}

To determine exactly what kind of values, the components of interpersonal dealings and social aspects specify Russian and English literary texts a full classification of the subcategories 'values', 'interpersonal dealings' and 'purely social' in the category 'social' markemes was also performed. In the subcategory 'values' we distinguished separately human (правда, свобода, справедливость, несправедливость), moral (добродетель, licentiousness) and aesthetic (искусство, красота, прелесть) values. In the subcategory 'interpersonal dealings' we separate communication (вьражение, молчан $(u / b) e)$, in the subcategory 'purely social' - social and economic (бо- 
гатство, extravagance, magnificence, respectability), social-political (ucтория, отечество), sociocultural (образование, просвещение), eventrelated (несчастие, торжество, catastrophe, misfortune), evaluative (insignificance) and performance (accomplishment, improvement, originality).

The relative weight of markemes in each category / subcategory has been computed according to the formula

$$
W=\frac{\sum i_{k}}{\sum i} \times 100,
$$

where $\mathrm{W}$ - the relative weight, $\sum i_{k}$ - the number of markemes in a separate category/subcategory, $\sum i$ - the total number of linking markemes. So, the relative weight of the subcategory 'emotional 'markemes in Russian texts is equal to $W=\frac{22}{100} \times 100=22 \%$, whereas, in English texts, the relative weight of the same markeme subcategory is $W=\frac{16}{86} \times 100=18,6 \%$. The relative weight of each markeme category/subcategory has been computed in a similar way. Table 7 presents the data obtained.

Table 7

\section{Linking markemes distribution in categories}

\begin{tabular}{|l|c|c|}
\hline \multicolumn{1}{|c|}{ Category / Subcategory } & Russian literature & British literature \\
\hline emotional & $22 \%$ & $18,60 \%$ \\
\hline fundamental & $17 \%$ & $11,60 \%$ \\
\hline mental & $14 \%$ & $26,70 \%$ \\
\hline intrinsic & $12 \%$ & $15,1 \%$ \\
\hline Social and economic & $6 \%$ & $3,50 \%$ \\
\hline interpersonal dealings & $6 \%$ & $16,3 \%$ \\
\hline natural fact & $4 \%$ & \\
\hline physical parameters of a person & $4 \%$ & \\
\hline human values & $4 \%$ & \\
\hline aesthetic values & $3 \%$ & \\
\hline communicative & $2 \%$ & \\
\hline space & $2 \%$ & \\
\hline moral values & $1 \%$ & $1,2 \%$ \\
\hline event-related & $2 \%$ & $2,30 \%$ \\
\hline mystical & $1 \%$ & \\
\hline evaluative & & $1,2 \%$ \\
\hline performance & & $3,50 \%$ \\
\hline
\end{tabular}

To specify linking markemes both for Russian and English texts we perform a procedure of determining the difference in the relative weights of markemes for each category / subcategory. Positive difference specifies the category for Russian texts and the negative difference does the same for English texts (Fig. 13).

The semantic group 'natural fact', the category of 'fundamental' markemes, the subcategories of 'corporal' and 'emotional' markemes of the 'personal' category and subcategories 'values', 'communicative interpersonal dealings', 'purely social' of the 'social' markemes category specify Rus- 
sian texts. The subcategories of 'mental' and 'intrinsic' markemes of the 'personal' category and the subcategories 'interpersonal dealings' and 'purely social' markemes of the 'social' category specify English texts.

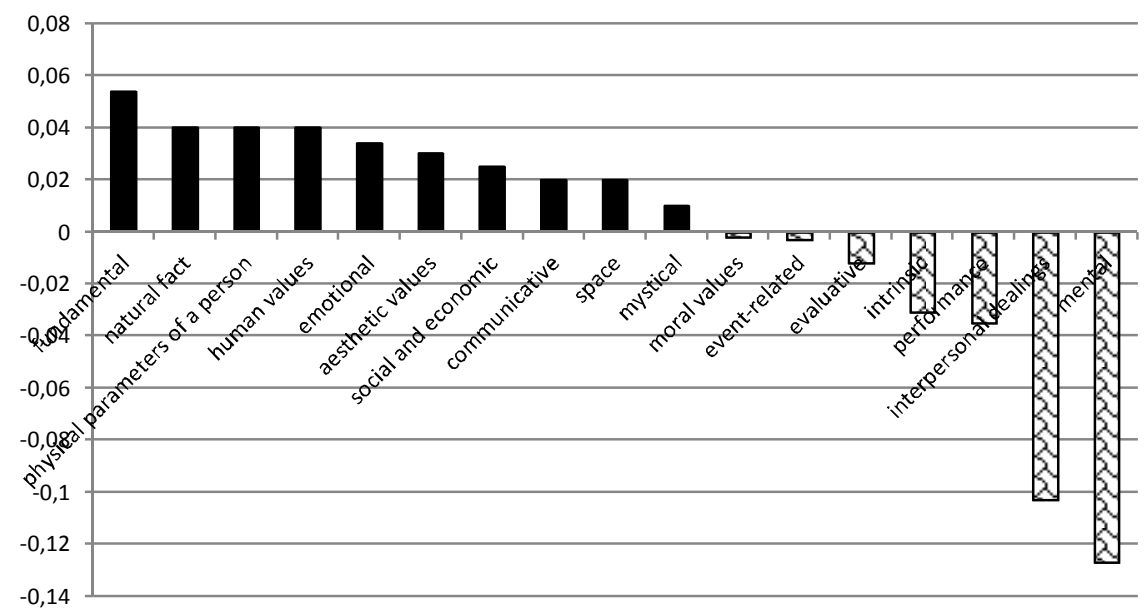

Figure 13. Markeme specificity of Russian and English texts

\section{Conclusions}

The comparison of the specific linking markemes vocabulary in the centers of attraction among Russian and English authors reveals the existence of only 4 coinciding markemes - воображение $(96,2369)$ - imagination $(3,8589)$, наслаждение $(24,4416)$ - gratification $(1,6676)$, обязанность $(11,2366)$ - responsibility $(1,7431)$, удовольствие $(8,6114)$ - satisfaction $(3,9324)$. Russian literary texts show great InLWeight exceedance of those markemes. Minimum exceedance is 2,2 times for markemes удовольствие - satisfaction, maximum exceedance is 24,9 times for воображение - imagination.

On the whole among specific markemes in the Russian centers of attraction there distinguished markemes that describe a person as a human being, his physique (человек, голова, здоровье), nature-made objects and natural phenomena (воздух, звезда, природа, солнце). Among Russian markemes, there also distinguished markemes that relate to such philosophical categories as время, мгновение, провиденье, свобода, счастье. Nevertheless, the major part of the specific markemes characterizes a person as a personality and a member of the society. These are emotional and mental markemes and markemes, which describe personality traits, ideals, values, and rules. There are five Russian linking markemes with negative semantics - невежество, недостаток, несчастие, страданье, призрак. It is 5\% of the total number of linking markemes. 
Among specific English markemes, there are markemes which characterize a person as a personality and a member of the society. There are seven markemes with negative semantics - disappointment, mortification, indignation, dissatisfaction, destruction, difficulties, and interference. It is $8 \%$ of the total number of linking markemes. There are no other semantic categories of English markemes.

In Russian literary texts there distinguished 3 major semantic groups of markemes - 'anthropological', 'abstract' and 'natural fact'. There is no semantic group 'natural fact' in English texts. Maximum relative weight characterizes the 'anthropological' group of markemes in each literature. Russian 'anthropological' markemes constitute 77\%, English markemes $88.4 \%$. It is followed by the 'abstract' group, in which the relative weight of Russian markemes is $19 \%$ and of English markemes - 11.6\%, and the group 'natural fact' whose relative weight is $4 \%$ for Russian markemes only. The relative weight of English 'anthropological' markemes is $11.4 \%$ higher than that of Russian ones whereas the relative weight of Russian 'abstract' markemes is $7.4 \%$ higher than that of English ones.

Thus, the semantic group 'natural fact', the category of 'fundamental' markemes, subcategories of 'corporal' and 'emotional' markemes of the 'personal' category and subcategories 'values', 'communicative interpersonal dealings', 'purely social' of the 'social' markemes category specify Russian texts. The subcategories of 'mental' and 'intrinsic' markemes of the 'personal' category and the subcategory of 'interpersonal dealings' and 'purely social' of the 'social' markeme category determine markeme specificity of English texts.

\section{References}

1. Malysheva, N.V.: Quantitative linguistics in modern scientific paradigm. Nauchnometodicheskij elektronnyj zhurnal Koncept, vol. 20, pp. 546-550 (2014) http://ekoncept.ru/2014/54373.htm (Accessed: January 6, 2019).

2. Verkhoturov, A.D., Mikhailovich, V.M., Voronov, B.A., Konevtsov, L.A.: On a new definition of science due to the necessity to solve global human problems including environmental, Uchenyje zapiski Komsomol'skogo-na-Amure gosudarstvennogo tehnicheskogo universiteta, vol. 1, no. 3 (15), pp. 86-93 (2013)

3. Miles, J.: The continuity of poetic language; the primary language of poetry, 1540 's-1940's, NY, Octagon Books (1965)

4. Lasswell, H.D.: Language of politics: Studies in quantitative semantics, Cambridge (Mass), M.I.T. Press (1949)

5. Heuser, R., Long Le-Khac: A Quantitative Literary History of 2,958 Nineteenth-Century British Novels: The Semantic Cohort Method, Literary Lab Pamphlet 4. https://litlab.stanford.edu/LiteraryLabPamphlet4.pdf (Accessed: December 15, 2018).

6. Heuser, R., Moretti, F., Steiner, E.: The Emotions of London, Literary Lab Pamphlet 13 (2016). https://itlab.stanford.edu/LiteraryLabPamphlet13.pdf(Accessed: December 15, 2018).

7. Algee-Hewitt, M., Allison, S., Gemma, M., Heuser, R., Moretti, F., Walser, H.: Canon/Archive. Large-scale Dynamics in the Literary Field, Literary Lab Pamphlet 11 (2016). https://litlab.stanford.edu/LiteraryLabPamphlet11.pdf (Accessed: December 15, 2018). 
8. Algee-Hewitt, M., Heuser, R., Moretti, F.: On Paragraphs. Scale, Theme, and Narrative Form, Literary Lab Pamphlet 10 (2015). https://itlab.stanford.edu/ LiteraryLabPamphlet 10.pdf (Accessed: December 15, 2018).

9. Allison, S., Gemma, M., Heuser, R., Moretti, F., Tevel, A., Yamboliev I.: Style at the Scale of the Sentence, Literary Lab Pamphlet 5 (2013) https:/litlab.stanford.edu/LiteraryLabPamphlet5.pdf (Accessed: December 15, 2018).

10. Kretov, A.A.: Karamzin in Japan, Filologicheskije zapiski: Vestnik literaturovedenija i jazykoznanija, 14, pp. 273-278 (2000)

11. Slugina, O.V. Linguo-cognitive fundamentals of poetic quantitativeness: English language material, Ph.D. Thesis, Philology, N.P. Ogarev Mordovia State University, Saransk, Russia (2009)

12. Borunov, A.B.: Parametric stratification of author's English-language corpus (author's corpus of American writer Raghu N. Mitra), Filologicheskije nauki. Voprosy teorii i praktiki, vol. 1 (of 4), 12 (66), pp. 65-68 (2016)

13. Borunov, A.B.: Quantitative study of English-language corpus of Raghu N. Mitra, Litera, 1, pp. 76-87 (2017) http://e-notabene.ru/fil/article_20090.html (Accessed: December 5, 2018).

14. Kishinskaya, L.G., Kishinskiy, S.V.: Revealing of the advanced role of poetic language in the language evolution by means of a correlation analysis, Uchenyje zapiski Tartuskogo gosudarstvennogo universiteta. Lingvostatika i kvantitativnyje zakonomernosti teksta. Trudy po lingvistike, vol. VI, pp. 47-58 (1980)

15. Krylov, S.A.: Corpus linguistics and quantitative analysis of Russian poetic texts, Problems of speech production and perception, Materialy X vyjezdnoj shkoly-seminara, Cherepovets, Russia, pp. 137-148 (2011)

16. Orekhov, B.V.: Digital approaches to "chamber fourrier journal" of V.F. Khodasevich, Russkaja literatura, 3, pp. 19-53 (2018)

17. Levin, Yu I.: About frequency dictionary of a poet's language, Russkaja literatura, 2, pp. 5-36 (1972)

18. Shaikevich, A.Ya., Andryushchenko, V.M., Rebetskaya, N.A.: Statistical vocabulary of Dostoyevskiy's language, Yazyki slav'anskoj kul'tury, Moscow, Russia (2003)

19. Faustov, A.A.: "Literary universals: towards terminological demarcation", Universalii russkoj literatury: sbornik statej, pp. 8-28. (2009a)

20. Faustov, A.A.: From keywords to literary universals: some methodological thoughts, Vestnik Voronezhskogo gosudarstvennogo universiteta. Serija Lingvistika i mezhkul'turnaja kommunikacija, 2, pp. 7-11 (2009b)

21. Faustov, A.A.: On literary texts fractions: to notion justification, Vestnik Voronezhskogo gosudarstvennogo universiteta. Serija Lingvistika i mezhkul'turnaja kommunikacija, 2, pp. 34-39 (2012)

22. Kretov, A.A.: First effort of A.V. Koltsov poetry archetype determination, Lingvistychni studii. Zbirnyk naukovyh prac', vol. 16, pp. 353-366 (2008)

23. Kashkina, A.V.: Quantitative analysis of Russian poets' vocabulary in the first half of the $18^{\text {th }}$ century, Yazyk, kommunikacija i social'naja sreda: sbornik nauchnyh trudov, vol. 7, pp. 194-211 (2009)

24. Faustov, A.A.: Markeme portrait of Anton P. Chekhov, Vestnik Voronezhskogo gosudarstvennogo universiteta. Serija Lingvistika i mezhkul'turnaja kommunikacija, 2, pp. 12-16 (2010)

25. Artemova, O.G.: L. Stern's writing as a markeme phenomenon of English fictional prose, Vestnik Voronezhskogo gosudarstvennogo universiteta. Serija Lingvistika i mezhkul'turnaja kommunikacija, 1, pp. 37-42 (2017)

26. The Digital Humanities Manifesto $2.0 \mathrm{http} / /$ humanities-blast.com/manifesto/Manifesto V2.pdf (Accessed: January 12, 2019).

27. Mozhaeva, G.V.: Digital Humanities: the digital turn in the humanities, Gumanitarnaja informatika, vol. 9, pp. 8-22 (2015) 
28. Orekhov, B.V.: Calculations legitimize the humanities https://nplus1.ru/material/2017/ 12/28/dig-hum (Accessed: January 12, 2019).

29. Golenok, M.P., Osipova, N.O.: Digital Humanities: problematic field and future development, Nauchnoje obozrenije: elektronnyj zhurnal, 1 (2018) https://cyberleninka.ru/article/v/digital-humanities-problemnoe-pole-i-perspektivy-razvitiya(Accessed: January 12, 2019).

30. Kretov, A.A.: Method of formal extraction of thematically-neutral lexis (as illustrated by Old Slavonic texts), Vestnik Voronezhskogo gosudarstvennogo unversiteta. Serija Sistemnyj analiz i unformacionnyje tehnologii, 1, pp. 81-90 (2007)

31. Artemova, O.G.: Markeme features of A. Radcliff's writing, Text in cultural, historical, language world, Proceedings of the International virtual training conference, Moscow, Russia, pp. 178-185 (2017)

32. Artemova, O.G., Kretov, A.A.: Spot markeme analysis of British prose of $17^{\text {th }}-20^{\text {th }}$ centuries, Vestnik Voronezhskogo gosudarstvennogo universiteta. Serija Lingvistika i mezhkul'turnaja kommunikacija, 2, pp. 87-93 (2017)

33. Artemova, O.G.: Markeme composition of the English prose language in the first half of the $18^{\text {th }}$ century, Vestnik Voronezhskogo gosudarstvennogo universiteta. Serija Lingvistika i mezhkul'turnaja kommunikacija, 4, pp. 32-40 (2017)

34. Kretov, A.A., Sizonenko, Ye.I.: Megamarkemes in A.T. Tvardovsky's poetry, Russkij yazyk kak yavlenije nacional'noj kul'tury: problem sovremennogo sostojanija i dinamicheskogo razvitija. Sbornik nauchnyh statej k jubileju O.V. Zagorovskoj, pp. 46-64 (2011)

35. Kashkina, A.V.: $18^{\text {th }}$ century in Russian poetry from markeme analysis point of view, Educational Technologies in virtual linguo-communicative area, Proceedings of the $4^{\text {th }}$ International virtual conference on Russian philology, literature and culture, Yerevan, Armenia, pp. 109-113 (2011)

36. Artemova, O.G.: Unique character of L. Stern's texts in English prose sentimentalism, Vestnik Voronezhskogo gosudarstvennogo universiteta. Serija Lingvistika i mezhkul'turnaja kommunikacija, 3, pp. 31-38 (2017)

37. Artemova, O.G., Komarova, E.P., Kretov, A.A.: Evolution of markemic lexis on the basis of markeme research in chronological slices, Language and Culture, 42, pp. 19-38 (2018)

38. Kretov, A.A., Kashkina, A.V.: Reasons for markeme composition change in Russian poetic language of the $18^{\text {th }}-21^{\text {st }}$ centuries, Daidzhest -2010 : diplomnyje raboty facul'teta RGF VGU, 11, pp. 94-101 (2018)

39. Artemova, O.G. Kretov, A.A.: Markeme trajectories of Russian and English prose language, Vestnik Voronezhskogo gosudarstvennogo universiteta. Serija Lingvistika i mezhkul'turnaja kommunikacija, 1, pp. 165-173 (2018)

40. Kretov, A.A.: Markeme dynamics in Russian literature of the $18^{\text {th }}$ - the beginning of the $20^{\text {th }}$ centuries as the reflection of sociocultural processes, Political linguistics, 3 (33), pp. 141-150 (2010)

41. Kretov, A.A., Katov, M.V.: Through prism of markemes: N.V. Gogol in the nearest context of Russian literature, Vestnik Voronezhskogo gosudarstvennogo universiteta. Serija Lingvistika i mezhkul'turnaja kommunikacija, 2, pp. 12-21 (2009)

42. Kretov, A.A., Katov, M.V., Faustov, A.A.: First effort of linguistic genealogy (exemplified by N.V. Gogol), Problemy izuchenija zhivogo russkogo slova na rubezhe tys'acheletij, Materialy 5 vserossijskoj nauchno-prakticheskoj konferencii, Voronezh, Russia, pp. 76-83 (2009)

43. Kretov, A.A., Katov, M.V., Faustov, A.A.: Who else appeared form Gogol's 'Overcoat'? (First effort of statistic-linguistic genealogy), Materialy po russko-slav’anskomu jazykoznaniju, International collected articles, 30, pp. 45-52 (2010)

44. Kretov, A.A., Katov, M.V., Faustov, A.A.: Static-linguistic genealogy in Russian literature of the $18^{\text {th }}$ - the beginning of the $20^{\text {th }}$ centuries, Problemy kompjuternoj lingvistiki: sbornik nauchnyh trudov, 4, pp. 114-125 (2010) 
45. Artemova, O.G., Kretov, A.A.: Analysis of linking markemes in British prose of the latter half of the $17^{\text {th }}$ century, Mir lingvistiki i kommunikacii: elektronnyj nauchnyj zhurnal, 3 , pp. 70-88 (2018) http://tverlingua.ru/

46. Faustov, A.A., Kretov, A.A.: Concept of a markeme and preliminary results of Russian literature markeme analysis, Vestnik Voronezhskogo gosudarstvennogo universiteta. Serija Lingvistika i mezhkul'turnaja kommunikacija, 4, pp. 16-31 (2017)

47. Kashkina, A.V.: On classification of markemes, Vestnik Voronezhskogo gosudarstvennogo universiteta. Serija Lingvistika i mezhkul'turnaja kommunikacija, 1, pp. 97-99 (2011)

Information about the authors:

Artemova O.G. - Ph.D. (Philology), Associate Professor, the Department of Foreign Languages and Translation Technology, Voronezh State Technical University (Voronezh, Russia).E-mail: olgaartemova65@yandex.ru

Verbitskiy A.A. - Dr. Sc. (Edu), Professor, Academician, member of the Russian Academy of Education, professor of the Department of social and pedagogical psychology of MPGU. E-mail: asson1@rambler.ru

Komarova E.P. - Dr. Sc. (Edu), Professor, the Department of Foreign Languages and Translation Technology, Voronezh State Technical University (Voronezh, Russia).E-mail: vivtkmk@mail.ru

Kretov A.A. - Dr. Sc. (Phililogy), Professor, the Department of Theoretical and Applied Linguistics, Voronezh State University (Voronezh, Russia). E-mail: tipl@rgph.vsu.ru 